\title{
Differential Expression and Function of Nicotinic Acetylcholine Receptors in Subdivisions of Medial Habenula
}

\author{
Pei-Yu Shih, ${ }^{1}$ Staci E. Engle, ${ }^{1}$ Gyeon Oh, ${ }^{1}$ Purnima Deshpande, ${ }^{2}$ Nyssa L. Puskar, ${ }^{3}$ Henry A. Lester, 2 \\ and Ryan M. Drenan ${ }^{1}$ \\ ${ }^{1}$ Department of Medicinal Chemistry and Molecular Pharmacology, Purdue University, West Lafayette, Indiana 47907, and ${ }^{2}$ Division of Biology and \\ Biological Engineering and ${ }^{3}$ Division of Chemistry and Chemical Engineering, California Institute of Technology, Pasadena, California 91125
}

\begin{abstract}
Neuronal nAChRs in the medial habenula (MHb) to the interpeduncular nucleus (IPN) pathway are key mediators of nicotine's aversive properties. In this paper, we report new details regarding nAChR anatomical localization and function in MHb and IPN. A new group of knock-in mice were created that each expresses a single nAChR subunit fused to GFP, allowing high-resolution mapping. We find that $\alpha 3$ and $\beta 4 \mathrm{nAChR}$ subunit levels are strong throughout the ventral $\mathrm{MHb}(\mathrm{MHbV})$. In contrast, $\alpha 6, \beta 2, \beta 3$, and $\alpha 4$ subunits are selectively found in some, but not all, areas of MHbV. All subunits were found in both ChAT-positive and ChAT-negative cells in MHbV. Next, we examined functional properties of neurons in the lateral and central part of MHbV (MHbVL and MHbVC) using brain slice patch-clamp recordings. MHbVL neurons were more excitable than MHbVC neurons, and they also responded more strongly to puffs of nicotine. In addition, we studied firing responses of MHbVL and MHbVC neurons in response to bath-applied nicotine. Cells in MHbVL, but not those in MHbVC, increased their firing substantially in response to $1 \mu \mathrm{m}$ nicotine. Additionally, MHbVL neurons from mice that underwent withdrawal from chronic nicotine were less responsive to nicotine application compared with mice withdrawn from chronic saline. Last, we characterized rostral and dorsomedial IPN neurons that receive input from MHbVL axons. Together, our data provide new details regarding neurophysiology and $\mathrm{nAChR}$ localization and function in cells within the MHbV.
\end{abstract}

Key words: habenula; interpeduncular; nicotine; nicotinic; tobacco; withdrawal

\section{Introduction}

Recently, human genetic studies have uncovered a number of alleles that confer susceptibility to developing dependence to nicotine found in tobacco products (Bierut et al., 2007). The most striking risk alleles are located within a gene cluster on chromosome 15 containing the $\alpha 3, \beta 4$, and $\alpha 5 \mathrm{nAChR}$ genes (Saccone et al., 2007, 2009; Bierut et al., 2008). These nAChR subunits, particularly $\alpha 3$ and $\beta 4$, exhibit extremely high expression in both medial habenula $(\mathrm{MHb})$ and interpeduncular nucleus (IPN) (Dineley-Miller and Patrick, 1992; Marks et al., 1992). Several rodent studies indicate a key role for $\alpha 5$ - and/or $\beta 4$-containing nAChRs in modulating nicotine intake. For example, $\alpha 5 \mathrm{KO}$ mice consume significantly more nicotine than their $\alpha 5 \mathrm{WT}$ counterparts, and reexpression of $\alpha 5$ subunits in $\mathrm{MHb}$ of $\alpha 5 \mathrm{KO}$ mice restores aversion to high doses of nicotine (Fowler et al.,

Received Jan. 31, 2014; revised June 9, 2014; accepted June 12, 2014.

Author contributions: P.-Y.S., S.E.E., N.L.P., H.A.L., and R.M.D. designed research;P.-Y.S., S.E.E., G.O., P.D., N.L.P., and R.M.D. performed research; P.-Y.S., S.E.E., N.L.P., and R.M.D. analyzed data; P.-Y.S., S.E.E., H.A.L., and R.M.D. wrote the paper.

This work was supported by a Brain and Behavior Research Foundation (formerly National Alliance for Research on Schizophrenia and Depression) Young Investigator Award and National Institutes of Health Grant DA030396 to R.M.D., Grant DA028955 to H.A.L. and Michael J. Marks, and Grant NS034407 to Dennis A. Dougherty). We thank Elisha Mackey and Rahul Srinivasan for technical assistance.

The authors declare no competing financial interests.

Correspondence should be addressed to Dr. Ryan M. Drenan, Purdue University, Department of Medicinal Chemistry and Molecular Pharmacology, 575 Stadium Mall Drive, West Lafayette, IN 47907.E-mail: drenan@purdue.edu. DOI:10.1523/JNEUROSCI.0476-14.2014

Copyright $\odot 2014$ the authors $\quad 0270-6474 / 14 / 349789-14 \$ 15.00 / 0$
2011). In a complementary study, Frahm et al. (2011) found that overexpression of $\beta 4$-containing $\mathrm{nAChRs}$ in $\mathrm{MHb}$ enhances aversion to, and consequently reduces consumption of, nicotine. These studies, coupled with recent findings indicating the existence of distinct neuronal populations in ventral $\mathrm{MHb}(\mathrm{MHbV})$ (Aizawa et al., 2012), point to the need for a better understanding of $\mathrm{nAChR}$ function within specific cell populations in $\mathrm{MHbV}$.

Several nAChR subunits exhibit their highest expression level in the MHb (Perry et al., 2002). In addition, most nAChR subunits found in heteromeric receptors are expressed in $\mathrm{MHb}$ (Dineley-Miller and Patrick, 1992; Marks et al., 1992), which theoretically increases the number of distinct nAChR subtypes found in $\mathrm{MHb}$ compared with other brain areas. Several studies have attempted to identify important nAChR subtypes in $\mathrm{MHb}$ neurons. Robin Lester and colleagues identified $\alpha 3 \beta 4^{*}\left(^{*}=\right.$ subunits in addition to those listed may be found in the indicated pentameric receptor) $\mathrm{nAChRs}$ as the predominant subtype in $\mathrm{MHbV}$, with a minor contribution from $\beta 2^{\star} \mathrm{nAChRs}$ in some cells (Quick et al., 1999). Studies in mice expressing gain-offunction $\alpha 4 \mathrm{nAChR}$ subunits demonstrated expression and function of $\alpha 4^{\star}$ nAChRs in lateral MHbV neurons (Nashmi et al., 2007; Fonck et al., 2009).

Because of the small size of the MHb, prior studies using radioligand binding or mRNA in situ hybridization did not allow for high-resolution mapping of $\mathrm{nAChR}$ subunit localization in specific cell types within this brain area. Although basic electrophysiological features of $\mathrm{MHb}$ neurons are starting to be uncov- 
ered (Kim and Chang, 2005), we fail to understand how activation of $\mathrm{MHb} n \mathrm{AChRs}$ changes excitability of the neurons in which they reside and the circuits into which they are integrated. To address these shortcomings in our understanding of $\mathrm{MHb}$ nAChR function, we combined immunohistochemistry with brain slice patch-clamp electrophysiology using mouse models. We generated knock-in mouse strains expressing $\alpha 3, \alpha 4, \beta 2, \beta 3$, and $\beta 4 \mathrm{nAChR}$ subunits fused to GFP. Along with previously generated $\alpha 6$-GFP mice (Mackey et al., 2012), we localized six nAChR subunits in specific regions of MHb and IPN. Further, in recordings from $\mathrm{MHb}$ and IPN neurons in brain slices from C57BL/6 WT mice, we identified neuronal cell types that differ in their sensitivity to nicotine.

\section{Materials and Methods}

Materials. CNQX and picrotoxin were purchased from Tocris Bioscience, and all other drugs and chemicals not indicated above were purchased from Sigma-Aldrich.

Mice. C57BL/6 mice used for electrophysiology studies were purchased from The Jackson Laboratory. Bacterial artificial chromosome (BAC) transgenic mice expressing GFP-labeled $\alpha 6 \mathrm{nAChR}$ subunits were described previously (Mackey et al., 2012). Briefly, a BAC containing the $\alpha 6 \mathrm{nAChR}$ subunit gene was modified by recombineering to introduce a GFP sequence in-frame into the M3-M4 portion of the $\alpha 6$ open reading frame. This modified BAC was used to produce transgenic mice. In these mice, $\alpha 6$ nAChRs exhibit normal distribution in the brain, normal expression levels, and normal function (Mackey et al., 2012; Henderson et al., 2014). All groups of mice used in this study had approximately equal numbers of males and females. All mice were between 8 and 14 weeks old when experiments were conducted.

Construction and testing of GFP-labeled $\alpha 3$ and $\beta 4 n A C h R$ subunits. Mouse $\alpha 3$ and $\beta 4 \mathrm{nAChR}$ cDNAs in pCDNA3.1 were a generous gift from Jerry Stitzel (Institute for Behavioral Genetics, University of Colorado, Boulder, CO). GFP was inserted in-frame into the M3-M4 loop region of the $\alpha 3$ and $\beta 4 \mathrm{nAChR}$ subunit coding sequence. This insertion site yields normal, functional receptors when GFP (or similar fluorophore such as YFP or CFP) is inserted into $\alpha 4$ (Nashmi et al., 2003, 2007), $\alpha 6$ (Drenan et al., 2008a; Xiao et al., 2011; Mackey et al., 2012), $\beta 2$ (Nashmi et al., 2003), and $\beta 3$ (Drenan et al., 2008a) nAChR subunits. GFP insertion was executed using a modified, two-step QuikChange (Stratagene) reaction according to our previously published methods (Drenan et al., 2008a). Briefly, an Ala-Gly-Ala linker was inserted immediately $5^{\prime}$ and $3^{\prime}$ to the GFP coding sequence. AlaGlyAla-GFP-AlaGlyAla was inserted between residues Gly373 and Ala374 in mouse $\alpha 3$ and between residues Gly378 and Pro379 in mouse $\beta 4$. All DNA constructs were fully sequenced before use.

To verify that GFP-labeled $\alpha 3$ and $\beta 4 \mathrm{nAChR}$ subunits were functional, two-electrode voltage clamp in Xenopus laevis oocytes was conducted as previously described for other GFP-labeled nAChR subunits (Drenan et al., 2008a). Briefly, constructs were linearized and cRNA was produced using a T7 in vitro transcription kit (mMessage mMachine; Ambion). RNA yield was quantified with absorbance at $260 \mathrm{~nm}$. Highquality WT or GFP $\alpha 3: \beta 4$ cRNA was injected at a ratio of 2:3 by mass into stage $\mathrm{V}$ to VI $X$. laevis oocytes. After injection, oocytes were incubated for 1-4 d in ND-96 buffer (in mм: $96 \mathrm{NaCl}, 2 \mathrm{KCl}, 1 \mathrm{CaCl}_{2}, 1 \mathrm{MgCl}_{2}$, and 5 $\mathrm{HEPES} / \mathrm{NaOH}, \mathrm{pH}$ 7.6) supplemented with $50 \mu \mathrm{g} / \mathrm{ml}$ gentamycin and $2.5 \mathrm{~mm}$ sodium pyruvate. Two-electrode voltage clamp was performed using an OpusXpress 6000A (Molecular Devices). Oocytes were clamped at a holding potential of $-60 \mathrm{mV} ; 1 \mathrm{ml}$ of ND-96 solution containing ACh (concentrations indicated in Fig. 1A) was applied to clamped oocytes for $12 \mathrm{~s}$ followed by a $2 \mathrm{~min}$ wash with drug-free ND-96. Data were sampled at $50 \mathrm{~Hz}$ and filtered at $20 \mathrm{~Hz}$.

$n A C h R-G F P$ knock-in mice. Five additional knock-in mouse strains were generated and studied in this project, as summarized in Figure 1. These nAChR-GFP subunits were designed to insert a monomeric enhanced GFP (called here simply GFP) in-frame into the M3-M4 intracellular loop. The $\alpha 4$-GFP knock-in strain was constructed, bred, and backcrossed to C57BL/6 at Caltech (4 generations) using procedures previously used to generate mice with yellow fluorescent protein (YFP)tagged $\alpha 4$ subunits (Nashmi et al., 2007). Four strains were produced by genOway for the $\alpha 3, \beta 2, \beta 3$, and $\beta 4 \mathrm{nAChR}$ subunits. The exact insertion site of GFP in the nAChR open reading frame of $\alpha 4$-GFP, $\beta 2$-GFP, and $\beta 3$-GFP mice was previously described (Nashmi et al., 2003, 2007; Drenan et al., 2008a; Srinivasan et al., 2011). nAChR exon/intron structure is relatively conserved for the genes under study in this paper, and the coding sequence for the M3-M4 loop is contained within exon 5 of the $\mathrm{nAChR}$ genes we manipulated. For each $\mathrm{nAChR}$ gene, a targeting vector was constructed containing exon 5 with GFP fused in-frame in the desired position in the M3-M4 loop coding sequence. Several kilobases of 5' and $3^{\prime}$ sequence (relative to exon 5) were included to direct homologous recombination. A neomycin cassette flanked by loxP sites was inserted adjacent to the modified exon 5 in the targeting vector. A diphtheria toxin negative selection cassette was inserted adjacent to one of the homology arms $\left(5^{\prime}\right.$ or $\left.3^{\prime}\right)$.

Targeting vectors were linearized and electroporated into C57BL/6 embryonic stem cells. G418-resistant cell clones were isolated and amplified. First, clones were screened via PCR to identify those positive for both the $5^{\prime}$ and $3^{\prime}$ homologous recombination events. Next, clones positive in the $5^{\prime}$ and $3^{\prime}$ PCR assays were further evaluated for correct homologous recombination (and the absence of additional genomic rearrangements) via Southern blot with probes designed to detect both the $5^{\prime}$ and $3^{\prime}$ homologous recombination events. At least three positive ES cell clones were injected into 3.5-d-old embryos (blastocyst stage) derived from an albino C57BL/6 strain (C57BL/6J-Tyr $\left.r^{c-2 J} / \mathrm{J}\right)$, and reimplanted into pseudo-pregnant females and allowed to develop to term. Progeny males with evidence of high $(>50 \%)$ chimerism (based on black vs white coat color) were selected for further breeding after reaching sexual maturity. To both (1) breed chimeras to the F1 generation and (2) excise the neomycin selection cassette from the genome of the F1 progeny, chimeric males were mated with female C57BL/6 Cre-deleter (proprietary to genOway) mice. To confirm germline transmission, neoexcision, and maintenance of the proper homologous recombination event, F1 mice were genotyped via both PCR and Southern blot. Summarizing, all nAChR subunit GFP mice are extensively backcrossed to C57BL/6 ( $\alpha 6$-GFP, $\alpha 4$-GFP) or are fully isogenic with C57BL/6 ( $\beta 3$ GFP, $\beta 2$-GFP, $\beta 3$-GFP, and $\beta 4$-GFP). DNA sequences for all targeting vectors, Southern blotting probes, and PCR primers are available upon request.

Chronic nicotine treatment. To treat mice chronically with nicotine and to study nicotine withdrawal, mice were implanted with primed osmotic minipumps (model 2004; Alzet) filled with sterile saline or (-)-nicotine hydrogen-tartrate salt dissolved in sterile saline. Nicotine (free base) was delivered at a rate of $1 \mathrm{mg} / \mathrm{kg} / \mathrm{h}$ for $14 \mathrm{~d}$. On day 14, minipumps were surgically removed, and mice were killed $18-24$ h later for electrophysiology experiments. Alternatively, on day 14 after implantation, some mice were injected intrapertoneally with mecamylamine $(1 \mathrm{mg} / \mathrm{kg})$ to precipitate withdrawal. Mice were transcardially perfused $90 \mathrm{~min}$ after mecamylamine injection, brains were removed, sectioned (50 $\mu \mathrm{m}$ thickness), and stained with anti-c-Fos antibodies as described below.

Immunohistochemistry. For analysis of nAChR-GFP expression in mouse brain, mice under deep anesthesia were perfused transcardially with cold PBS followed by cold PBS containing 4\% PFA. Brains were postfixed overnight in 4\% PFA in PBS. Using MultiBrain Technology (NeuroScience Associates), nAChR-GFP brains were embedded in a gelatin matrix. After freezing the brain samples to $-70^{\circ} \mathrm{C}$ with dry ice, they were sliced coronally into $35-\mu \mathrm{m}$-thick serial sections using a microtome. For anti-GFP staining, the following procedures were followed. Sections were washed 3 times for 5 min per wash in TBS, followed by incubation in peroxide solution $\left(0.9 \% \mathrm{H}_{2} \mathrm{O}_{2}\right.$ in TBST, which is TBS containing $0.3 \%$ Triton $\mathrm{X}-100$ ) for $30 \mathrm{~min}$. Sections were rinsed 3 times for 5 min per wash in TBS, followed by incubation in blocking serum (normal horse serum diluted $80 \times$ into TBST) for $60 \mathrm{~min}$. Sections were rinsed 3 times for $5 \mathrm{~min}$ per wash in TBS, followed by incubation in primary antibody solution (rabbit anti-GFP; 1:5000; Millipore) overnight at room temperature. Sections were washed 3 times for 5 min per wash in TBS, followed by incubation in solution containing biotinylated 
A

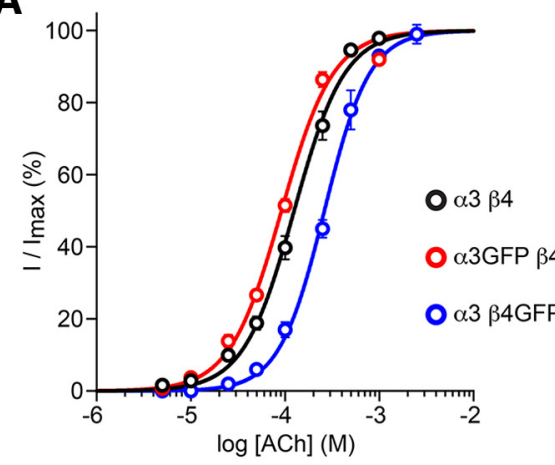

B

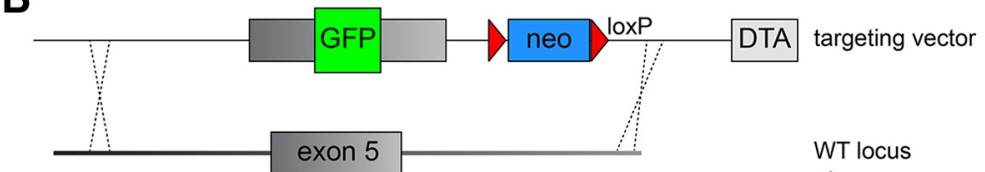

-gene targeting in ES cells
-blastocyst injection -produce chimeras

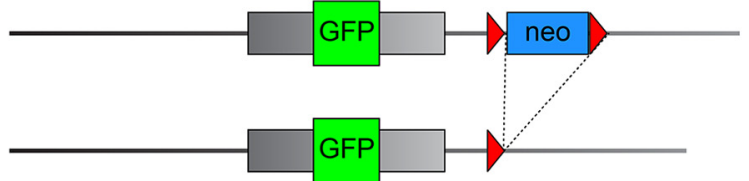

recombined locus

-cross to cre-deleter mice
-F1 germline transmission

neo-excised locus

Figure 1. Production of GFP-labeled nAChR subunits. $A$, Functional characterization of $\alpha 3$-GFP and $\beta 4$-GFP subunits. mRNA encoding WT or GFP-fused mouse $\alpha 3$ and $\beta 4 \mathrm{nAChR}$ subunits was transcribed and microinjected (ratio of $2 \alpha$ subunits: $3 \beta$ subunits) into X. laevis oocytes. Using two-electrode voltage clamp (holding potential $=-60 \mathrm{mV}$ ), inward current responses were recorded during application of $A C h$ at the indicated concentrations. Concentration-response curves were constructed, and data were fitted to the Hill equation. The number of oocytes analyzed was 11 (WT $\alpha 3 \beta 4), 11$ ( $\alpha 3$ GFP $\beta 4$ ), and 7 ( $\alpha 3 \beta 4$ GFP). B, The nAChR genes modified and/or reported on in this study are the following: $\alpha 3, \alpha 4, \alpha 6, \beta 2, \beta 3$, and $\beta 4$. For each of these genes, the M3-M4 intracellular loop is the site for insertion of monomeric GFP (abbreviated simply as "GFP") and is encoded by exon 5 . Except for the $\alpha 6$-GFP strain, for each of these nAChR subunit genes, a targeting vector was built that contained a modified (GFP inserted in-frame) exon 5, a neomycin selection cassette flanked by loxP sites, several kilobases of homologous 5 ' and 3' sequence (homology arms), and a diphtheria toxin-negative selection cassette. Targeting vectors were linearized and electroporated into mouse embryonic stem cells. GFP insertion into exon 5 was verified as described in Materials and Methods, targeted ES cell clones were injected into blastocysts, and blastocysts were implanted into pseudopregnant surrogates. Chimeric mice were crossed to Cre-deleter mice to remove the neomycin selection cassette in vivo, and correct gene targeting in neo-excised, F1 progeny was analyzed and verified.

A
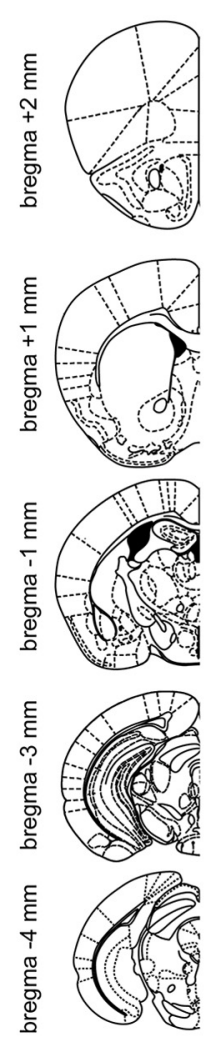

B

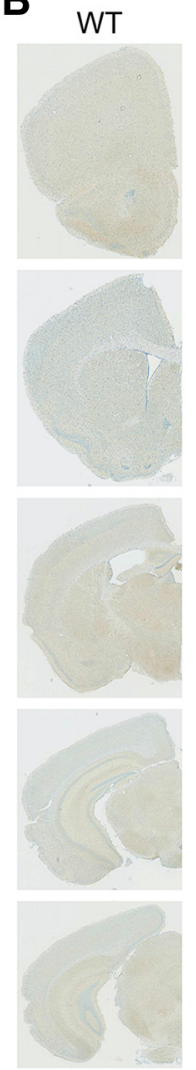

C

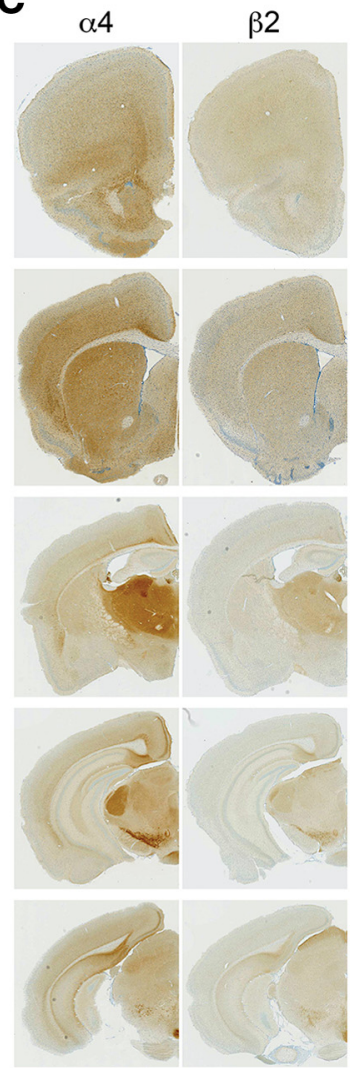

D

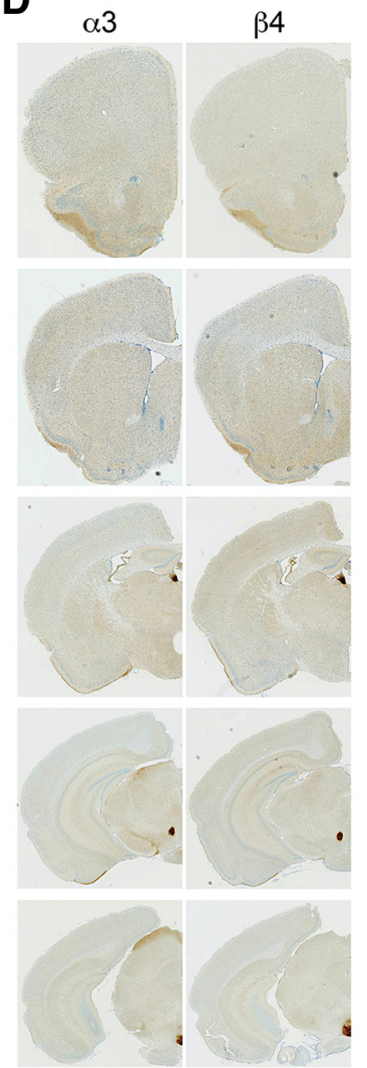

$\mathbf{E}$

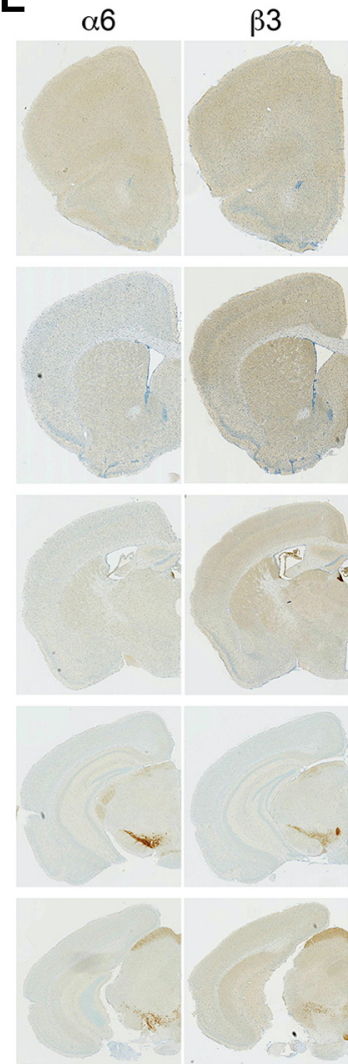

Figure 2. Localization of GFP-fused $\mathrm{nAChR}$ subunits in mouse brain. $A$, Brain atlas diagram for five bregma coordinates (bregma $2 \mathrm{~mm}, 1 \mathrm{~mm},-1 \mathrm{~mm},-3 \mathrm{~mm},-4 \mathrm{~mm}$ ) corresponding to approximate bregma coordinates for data presented in $\boldsymbol{B}-\boldsymbol{E}$. $\boldsymbol{B}-\boldsymbol{E}$, Brains from six mouse strains expressing GFP-fused nAChR subunits were fixed, sectioned at $35 \mu \mathrm{M}$, and stained with anti-GFP antibodies. $\boldsymbol{B}$, C57BL/6 WT brains were processed as a staining negative control. A representative (of $n=3$ ) image of a coronal section is shown for each nAChR-GFP mouse strain at the indicated anterior/posterior coordinate. $\alpha 4$ and $\beta 2(\boldsymbol{C}), \alpha 3$ and $\beta 4(\boldsymbol{D})$, and $\alpha 6$ and $\beta 3(\boldsymbol{E})$ were grouped together based on their coexpression in several brain areas.

secondary antibodies (goat anti-rabbit biotinylated IgG; 1:240; Vector Laboratories) for $60 \mathrm{~min}$. Sections were washed 3 times for 5 min per wash in TBS, followed by incubation in ABC solution (TBST containing Reagent A and B solutions, VECTASTAIN Elite ABC System; Vector Laboratories) for $120 \mathrm{~min}$. Sections were washed 3 times for $5 \mathrm{~min}$ per wash, followed by incubation for $0-10 \mathrm{~min}$ in $\mathrm{DAB}-\mathrm{H}_{2} \mathrm{O}_{2}$ solution
( $0.00017 \%$ DAB diluted into TBST containing $0.0015 \% \mathrm{H}_{2} \mathrm{O}_{2}$ ) with continuous visual monitoring of DAB staining. Sections were washed 2 times for 5 min per wash, placed in fresh TBS, mounted onto glass slides, and coverslipped.

Some sections cut by NeuroScience Associates were stained at Purdue and imaged with confocal microscopy. For those, as well as c-Fos stain- 
ing, the following procedures were followed. Sections were collected into 12-well tissue culture plates, washed 3 times for 10 min per wash in TBS, and blocked for $30 \mathrm{~min}$ in TBST containing $10 \%$ normal horse serum. Sections were washed 3 times for 10 min per wash and incubated in a solution containing TBST and primary antibodies (rabbit anti-GFP; 1:500; Invitrogen; rabbit anti-c-Fos; 1:400; Santa Cruz Biotechnology; and goat anti-ChAT; 1:100; Millipore) overnight at $4^{\circ} \mathrm{C}$. Sections were washed 3 times for $10 \mathrm{~min}$ per wash in TBST and incubated in a solution containing secondary antibodies (chicken anti-rabbit Alexa-488; 1:500; Invitrogen; and/or donkey anti-goat Alexa-555; 1:500; Invitrogen) for 1-2 $\mathrm{h}$ at room temperature. Sections were then rinsed 3 times for 10 min per rinse, mounted onto glass slides, and coverslipped for confocal microscopy.

To test for colocalization of recorded neurons with ChAT, brain slices with neurobiotinfilled neurons were fixed overnight in 4\% PFA in PBS and processed essentially as described above for confocal microscopy but with the following modifications. Sections were washed 2 times for 10 min per wash in PBS, blocked, and permeabilized in PBS containing 10\% normal horse serum, 2\% BSA and $0.3 \%$ Triton X-100 (PBST) for $60 \mathrm{~min}$. Sections were incubated with PBST solutions containing primary antibody (goat anti-ChAT; 1:500; Millipore and streptavidin conjugated Alexa-488; 1:1000; Invitrogen) overnight at $4^{\circ} \mathrm{C}$. Sections were washed 3 times for 5 min per wash with PBS, followed by incubation in PBST solutions containing secondary antibodies (Alexa-555 donkey-anti-goat; 1:500; Invitrogen) for $120 \mathrm{~min}$ at room temperature. Finally, sections were washed 3 times for 10 min per wash with PBS, mounted with anti-fade mounting medium (Vectashield; Vector Laboratories), and coverslipped.

Brain slice preparation for electrophysiology. Two- to 3-month-old C57BL/6J mice (The Jackson Laboratory) and $\alpha 4$ knock-out (KO) mice of either sex were used in accordance with the guidelines of the National Institutes of Health Office of Laboratory Animal Welfare, and the protocols were approved by the Institutional Animal Care and Use Committee at Purdue University. Mice were anesthetized by intraperitoneal injection of a sodium pentobarbital $(200 \mathrm{mg} / \mathrm{kg})$, followed by transcardiac perfusion with oxygenated $\left(95 \% \mathrm{O}_{2} / 5 \% \mathrm{CO}_{2}\right) \mathrm{N}$-methyl-D-glucamine (NMDG) recovery solution (in mM: $93 \mathrm{NMDG}, 2.5 \mathrm{KCl}, 1.2 \mathrm{NaH}_{2} \mathrm{PO}_{4}$, $30 \mathrm{NaHCO}_{3}, 20$ HEPES, 25 glucose, $5 \mathrm{Na}^{+}$ascorbate, 2 thiourea, $3 \mathrm{Na}^{+}$ pyruvate, $10 \mathrm{MgSO}_{4} \cdot 7 \mathrm{H}_{2} \mathrm{O}, 0.5 \mathrm{CaCl}_{2} \cdot 2 \mathrm{H}_{2} \mathrm{O}$, with $\mathrm{pH}$ adjusted to $7.3-$ $7.4,300-310 \mathrm{mOsm})$. The brain was quickly removed into ice-cold NMDG recovery solution for $1 \mathrm{~min}$, and $200-\mu \mathrm{m}$-thick coronal slices containing MHb or IPN were cut with a vibrating microslicer (DTKZero 1; Ted Pella). Coordinates were as follows: (MHb: -1.9 anterior/ posterior, 0.25 lateral, $-2.5 \mathrm{dorsal} / \mathrm{ventral}$; IPN: -3.5 anterior/posterior, 0.0 lateral, $-4.5 \mathrm{dorsal} / \mathrm{ventral})$. Slices were then incubated in this solution at $33^{\circ} \mathrm{C}$ for $12 \mathrm{~min}$, after which they were kept at room temperature for at least $1 \mathrm{~h}$ in $95 \% \mathrm{O}_{2} / 5 \% \mathrm{CO}_{2}$-equilibrated HEPES-holding-solution containing the following (in $\mathrm{mm}$ ): $\mathrm{NaCl} 92, \mathrm{KCl} 2.5, \mathrm{NaH}_{2} \mathrm{PO}_{4}$ 1.2, $\mathrm{NaHCO}_{3} 30$, HEPES 20, glucose 25, $\mathrm{Na}^{+}$ascorbate 5, thiourea 2, $\mathrm{Na}^{+}$ pyruvate $3, \mathrm{MgSO}_{4} \cdot 7 \mathrm{H}_{2} \mathrm{O} 2$, and $\mathrm{CaCl}_{2} \cdot 2 \mathrm{H}_{2} \mathrm{O} 2$.

Patch-clamp electrophysiology. Recordings were made under an upright microscope (Nikon Eclipse FN-1) equipped with infrared differential interference contrast optics for visualization. Slices were transferred to a recording chamber superfused with standard recording ACSF containing (in mM) NaCl 124, $\mathrm{KCl} 2.5, \mathrm{NaH}_{2} \mathrm{PO}_{4} 1.2, \mathrm{NaHCO}_{3} 24$, glucose $12.5, \mathrm{MgSO}_{4} \cdot 7 \mathrm{H}_{2} \mathrm{O} 2$, and $\mathrm{CaCl}_{2} \cdot 2 \mathrm{H}_{2} \mathrm{O}$ 2, adjusted to $\mathrm{pH} 7.3-7.4,300$ $310 \mathrm{mOsm}$. Recordings were performed at $32^{\circ} \mathrm{C}$. Patch pipettes were made from borosilicate glass capillary tubing (1B150F-4; World Precision Instruments) using a micropipette puller (P-97; Sutter Instrument). The internal recording pipette solution contained the following (in $\mathrm{mM}$ ): $\mathrm{K}^{+}$gluconate 135, EGTA 5, HEPES 10, MgATP 2, NaGTP 0.1, $\mathrm{CaCl}_{2} 0.5$, $\mathrm{MgCl}_{2} 2 ; \mathrm{pH}$ adjusted to 7.3 with Tris base. In a subset of experiments, 2.5 $\mathrm{mg} / \mathrm{ml}$ neurobiotin (Vector Laboratories) was added to the internal solution for intracellular labeling of recorded neurons, and the $\mathrm{pH}$ was readjusted. Currents were recorded using a Multiclamp 700B or an Axopatch 200B amplifier with a DigiData 1440A interface and Clampex 10.3 software (Molecular Devices) sampled at $5 \mathrm{kHz}$ and low-pass filtered at 1 $\mathrm{kHz}$. Series resistance was uncompensated.

For some drug applications, CNQX $(10 \mu \mathrm{M})$, picrotoxin $(100 \mu \mathrm{M})$, and atropine $(1 \mu \mathrm{M})$ were added to the superfusion ACSF by dilution of a stock solution. Functional AMPAR and nAChR responses were examined as previously described (Engle et al., 2012, 2013). Briefly, a drugfilled glass pipette, identical to a typical recording pipette, was connected to a micropressure ejection system (PV-820 Pneumatic PicoPump; World Precision Instruments). Ejection pipettes were moved to within $20-40 \mu \mathrm{m}$ of the recorded cell using a piezoelectric manipulator (PA100/12; Piezosystem Jena), drug was applied for $250 \mathrm{~ms}$ (12 psi), and the ejection pipette was retracted.

Statistics and data analysis. Summary data are presented in the text and figures as the mean \pm SEM $t$ tests (unpaired or paired, as indicated in figure legends) were used for all comparisons. All statistical tests were performed using Graphpad software (Prism). Concentration-response data were fitted to the Hill equation. Differences were considered significant at $p<0.05$.

\section{Results}

We previously verified that XFP-tagged $\alpha 4$ (Nashmi et al., 2003, 2007), $\beta 2$ (Nashmi et al., 2003), $\alpha 6$ (Drenan et al., 2008a; Xiao et al., 2009, 2011; Mackey et al., 2012), and $\beta 3$ (Drenan et al., 2008a) subunits are functional in cell expression systems and in vivo in 
A
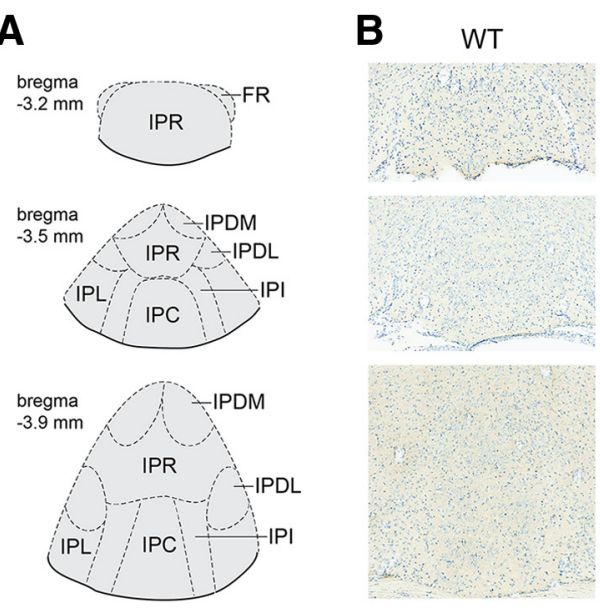

C
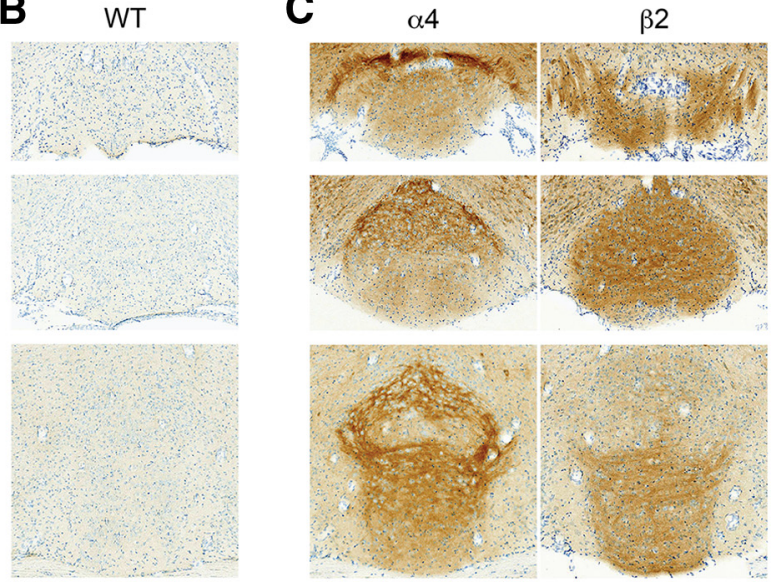

D

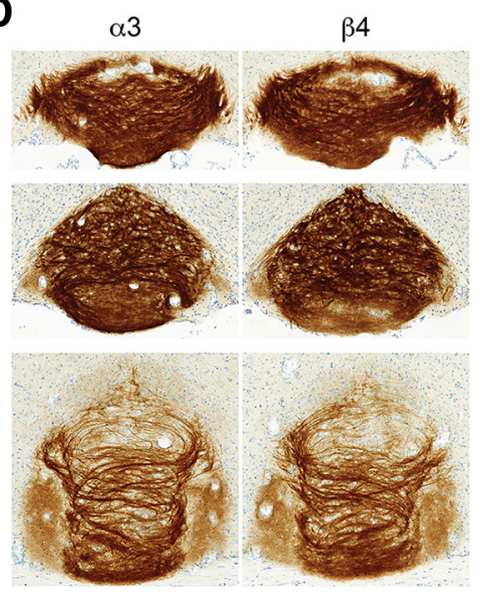

E $\alpha 6$

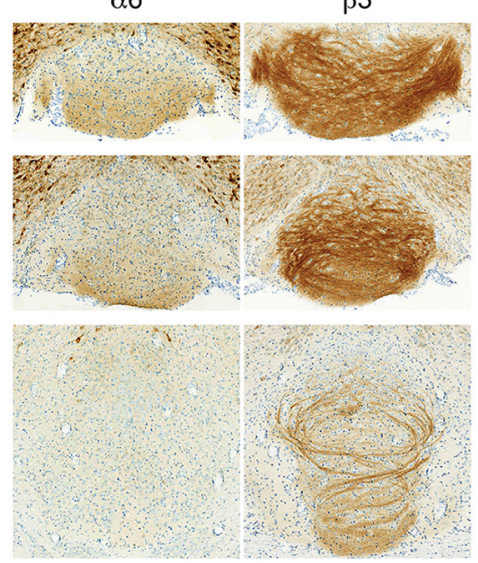

Figure 4. Localization of GFP-fused nAChR subunits in IPN. A, Brain atlas diagram for 3 bregma coordinates (bregma $-3.2 \mathrm{~mm}$, $-3.5 \mathrm{~mm}$, and $-3.9 \mathrm{~mm}$ ) corresponding to anterior, medial, and posterior interpeduncular nucleus. $\boldsymbol{B}-\boldsymbol{E}$, Brains from six mouse strains expressing GFP-fused nAChR subunits were fixed, sectioned at $35 \mu \mathrm{m}$, and immunostained with anti-GFP antibodies. $\boldsymbol{B}$, C57BL/6 WT brains were processed as a staining negative control. A representative (of $n=3$ ) image of an IPN coronal section is shown for each nAChR-GFP mouse strain at the indicated anterior/posterior coordinate. $\alpha 4$ and $\beta 2(\boldsymbol{C}), \alpha 3$ and $\beta 4(\boldsymbol{D})$, and $\alpha 6$ and $\beta 3(\boldsymbol{E})$ were grouped together based on coexpression in $\mathrm{MHb}$ and/or other brain areas.

some cases, but we have not previously demonstrated the same for $\alpha 3$-GFP and $\beta 4$-GFP subunits. To verify that these latter subunits are indeed functional, mRNA for $\alpha 3$-GFP and $\beta 4$-GFP $\mathrm{nAChR}$ subunits was transcribed and microinjected into $X$. laevis oocytes. To mimic expression of these GFP-labeled subunits in the knock-in mice, $\alpha 3$-GFP was expressed with WT $\beta 4$ subunits, and $\beta 4$-GFP was expressed with WT $\alpha 3$ subunits. WT $\alpha 3 \beta 4$ receptor function was compared as a reference. ACh was applied to voltage-clamped oocytes for $1 \mathrm{~s}$, and peak current responses were measured. Mean data $( \pm$ SEM) were plotted and fitted to the Hill equation for WT $\alpha 3 \beta 4, \alpha 3$-GFP $\beta 4$, and $\alpha 3 \beta 4$-GFP nAChRs. Both $\alpha 3$-GFP and $\beta 4$-GFP subunits supported relatively normal nAChR function compared with WT $\alpha 3 \beta 4 \mathrm{nAChRs}$ (Fig. 1A).

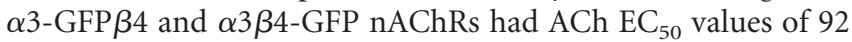
$\mu \mathrm{M}$ (95\% confidence interval: $81-105 \mu \mathrm{M})$ and $262 \mu \mathrm{M}(95 \%$ confidence interval: $246-279 \mu \mathrm{M}$ ) and Hill coefficients of $1.6 \pm$ 0.1 and $1.8 \pm 0.1$, respectively. Reference WT $\alpha 3 \beta 4 \mathrm{nAChRs}$ had an $\mathrm{ACh} \mathrm{EC}_{50}$ value of $125 \mu \mathrm{M}$ (95\% confidence interval: 113-137 $\mu \mathrm{M})$ and a Hill coefficient of $1.6 \pm 0.1$, consistent with previous studies on this receptor (Fig. 1A) (Drenan et al., 2008a). We seek to make exon-replacement knock-in mice with a particular nAChR-GFP mutation only when the mutation is expected to result in a change in sensitivity of approximately twofold or less compared with the WT subunit. Although $\alpha 3 \beta 4$-GFP nAChRs did exhibit a slight reduction in sensitivity compared with WT $\alpha 3 \beta 4$ nAChRs in oocyte experiments (Fig. $1 A$ ), the change was approximately twofold in magnitude, so we proceeded with this GFP insertion to make $\beta 4$-GFP mice.

For each of the $\alpha 3, \alpha 4, \beta 2, \beta 3$, and $\beta 4$ $\mathrm{nAChR}$ genes, an exon replacement strategy in embryonic stem cells was used to insert an enhanced GFP sequence inframe into exon 5 of the nAChR gene (Fig. $1 B)$. This resulted in production of nAChR subunits with an intervening, functional GFP protein within the large, M3-M4 intracellular loop. In addition to these 5 new knock-in mouse strains, we also used BAC transgenic mice expressing GFP-fused $\alpha 6$ nAChR subunits, which have been reported previously (Mackey et al., 2012). nAChR-GFP mice were perfused and coronal sections were cut at 35 $\mu \mathrm{M}$ from bregma $2 \mathrm{~mm}$ to $-4 \mathrm{~mm}$ (Fig. $2 A)$. Sections were stained with anti-GFP antibodies and visualized with DAB histochemistry. Figure $2 B-E$ shows representative images of GFP-stained coronal sections for all GFP mice (and C57BL/6 WT control mice; Fig. $2 B$ ) at 5 different anterior/posterior coordinates (bregma 2, $1,-1,-3$, and $-4 \mathrm{~mm}$ ) corresponding to sites of known expression for these subunits. Subunits were grouped based on similar localization patterns in the brain: $\alpha 4$ and $\beta 2$ (Fig. 2C), $\alpha 3$ and $\beta 4$ (Fig. 2D), and $\alpha 6$ and $\beta 3$ (Fig. 2E). Based on known localization patterns using methods, such as radioligand binding and mRNA in situ hybridization, no aberrant localization of GFP-labeled subunits was apparent in our staining results (Fig. $2 B-E) . \alpha 4$ and $\beta 2$ subunits were distributed throughout the brain, including but not limited to cerebral cortex, striatum, thalamus (including dorsal lateral geniculate nucleus), $\mathrm{MHb}$, substantia nigra $(\mathrm{SN})$, ventral tegmental area (VTA), and superior colliculus (SC) (Fig. 2C). $\alpha 3$ and $\beta 4$ distribution was apparent in piriform cortex, MHb, fasciculus retroflexus (FR), and IPN, with additional $\alpha 3$ found apparent in SC (Fig. 2D). $\alpha 6$ was found at low levels in prefrontal cortex and striatum, MHb, SN, VTA, and SC (Fig. 2E). $\beta 3$, which has been difficult to localize in the brain because it does not participate in a nAChR agonist binding site (Drenan et al., 2008a), has moderate levels in cortical areas, ST, $\mathrm{MHb}, \mathrm{FR}, \mathrm{SN}, \mathrm{VTA}$, and SC (Fig. 2E).

To analyze nAChR localization in the MHb to IPN pathway, sections containing $\mathrm{MHb}$ (bregma -1 to $-2 \mathrm{~mm}$; Fig. $3 A$ ) and IPN (bregma -3.2 to $-3.9 \mathrm{~mm}$; Fig. $4 A$ ) were stained with antiGFP primary antibodies and peroxidase-conjugated secondary antibodies, followed by visualization with a DAB reaction. Terminology for $\mathrm{MHb}$ subnuclei follows a recent study (Aizawa et al., 2012). $\alpha 4, \beta 2$, and $\beta 4 \mathrm{nAChR}$ subunits are restricted to the ventral two-thirds of the $\mathrm{MHb}$ (referred to as MHbV) (Fig. $3 C, D) . \alpha 3, \alpha 6$, and $\beta 3$ subunits are also largely restricted to the 
MHbV, but immunoreactivity for these subunits is also evident in a small number of cells in the dorsal one-third of $\mathrm{MHb}$ (MHbD) (Fig. 3D,E). $\alpha 3$ and $\beta 4$ subunit localization is even and strong throughout the MHbV, with subunits also evident in efferent fibers that give rise to the FR (Fig. 3D). $\alpha 4$ subunits are exclusively found in the lateral portion of the MHbV (referred to as MHbVL) (Fig. 3C), consistent with previous reports (Nashmi et al., 2007; Fonck et al., 2009). In contrast to $\alpha 4, \alpha 6$ subunits are mainly found in the inferior portion of MHbV (MHbVI), with additional faint expression in the lateral portion of MHbD (Fig. 3E). $\beta 2$ subunit immunoreactivity is seen throughout $\mathrm{MHbV}$, with preference for central and inferior $\mathrm{MHbV}$ (Fig. 3C). $\beta 3$ subunits are strong in MHbVI and MHbVC but very weak in MHbVL (Fig. 3E).

Next, nAChR subunit localization was analyzed in IPN from bregma -3.2 to $-3.9 \mathrm{~mm}$ (Fig. $4 A$ ) using anti-GFP immunohistochemistry in $\mathrm{C} 57 \mathrm{BL} / 6 \mathrm{WT}$ (Fig. 4B) and nAChR-GFP knock-in mice (Fig. 4C-E). Terminology used for IPN subnuclei is consistent with Wada et al. (1989) and the mouse brain atlas (Franklin and Paxinos, 2008): rostral subnucleus (IPR), dorsomedial subnucleus (IPDM), dorsolateral subnucleus (IPDL), caudal subnucleus (IPC), and intermediate subnucleus (IPI). Similar to MHb, $\alpha 3$ and $\beta 4$ subunit levels are strong in IPR, IPDM, IPDL, IPC, and IPI, with moderate amounts of subunits also evident in IPL and IPDL (Fig. 4D). $\alpha 4$ subunits are strongest in IPR and IPDM, with lower levels of immunoreactivity evident in IPC and IPI (Fig. 4C). In contrast to $\alpha 4, \alpha 6$ subunits are found at low levels in ventral IPR and IPC with little to no $\alpha 6$ subunits found in dorsal IPR or IPDM (Fig. 4E). $\beta 2$ subunit levels are modest throughout the rostral IPN but are restricted to IPC and IPI in caudal IPN (Fig. 4C). $\beta 3$ levels are strong in most IPN subnuclei but were not found in dorsal IPR and/or IPDM (Fig. 4E).

The MHbV stains positive for cholinergic markers, such as ChAT and VAChT (Contestabile et al., 1987), and IPN nAChRs in presynaptic terminals from MHbV neurons are involved in ACh release (Grady et al., 2009). However, other reports indicate that MHbV neurons are glutamatergic and that $\mathrm{nAChRs}$ in presynaptic terminals in IPN are involved in regulating glutamate release (Ren et al., 2011; $\mathrm{Hu}$ et al., 2012). Using mouse strains expressing GFP-labeled nAChRs, we costained brain sections containing MHb with antiGFP and anti-ChAT primary antibodies. The MHb was imaged at $60 \times$ magnification using confocal microscopy. Anti-GFP staining recapitulated our $\mathrm{DAB}$ staining results with respect to anatomical specificity; $\alpha 3$ and $\beta 4$ subunits were found throughout
A
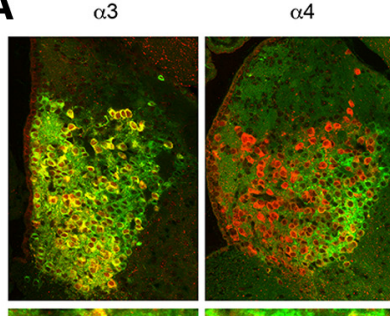

C
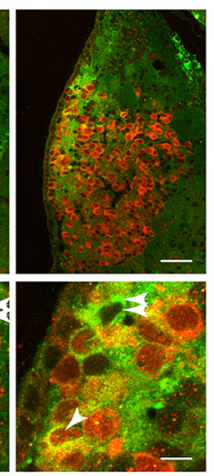

B
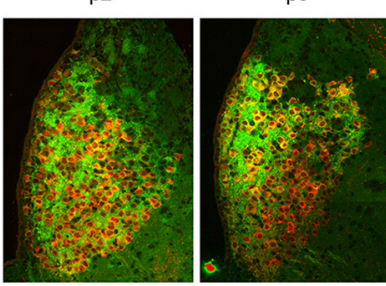

$\beta 4$
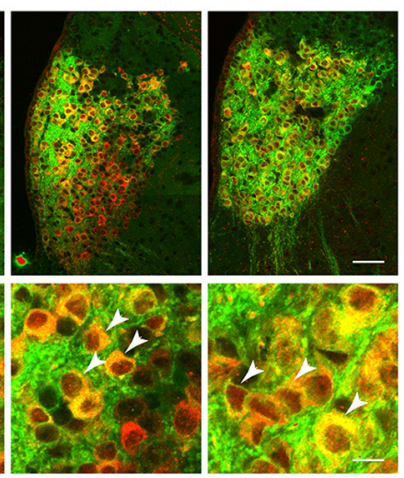
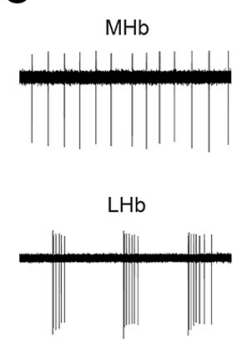

E

$\operatorname{ChAT}(+)$

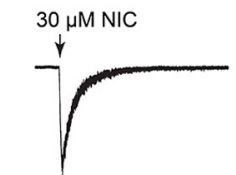

F

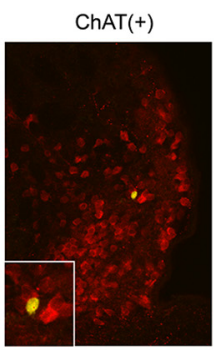

D

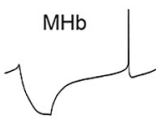

$\mathrm{LHb}$

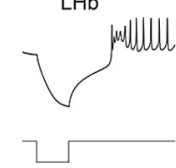

ChAT(-)
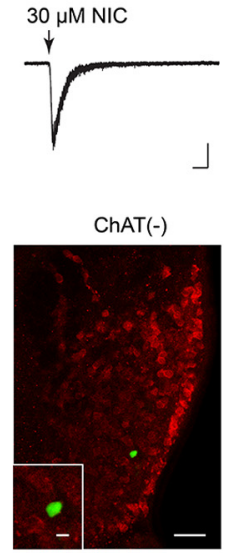

Figure 5. $\mathrm{nAChR}$ MHb localization and function in ChAT $(+)$ and ChAT( - ) cells. $\boldsymbol{A}$, For $\alpha 3$-GFP, $\alpha 4-$ GFP, and $\alpha 6$-GFP mouse strains, coronal MHb sections were prepared, double-stained with anti-GFP and anti-ChAT antibodies, and imaged using confocal microscopy. Merged (green represents anti-GFP; red represents anti-ChAT; yellow represents colocalized pixels) micrographs of the $\mathrm{MHb}$ (top panels), and a high-resolution zoom of several cells in $\mathrm{MHb}$ (bottom panels) are shown. Single, diagonal arrowheads indicate cells expressing both ChAT and the nAChR-GFP subunit. Double, horizontal arrowheads indicate cells expressing nAChRGFP subunits but not ChAT. Scale bars: top, $50 \mu \mathrm{m}$; bottom, $10 \mu \mathrm{m}$. B, For $\beta 2$-GFP, $\beta 3$-GFP, and $\beta 4-G F P$ mouse strains, coronal $\mathrm{MHb}$ sections were prepared, double-stained with anti-GFP and anti-ChAT antibodies, and imaged using confocal microscopy. Merged (green represents anti-GFP; red represents anti-ChAT; yellow represents colocalized pixels) micrographs of the MHb (top panels), and a high-resolution zoom of several cells in $\mathrm{MHb}$ (bottom panels) are shown. Single, diagonal arrowheads indicate cells expressing both ChAT and the nAChR-GFP subunit. Double, horizontal arrowheads indicate cells expressing nAChR-GFP subunits but not ChAT. Scale bars: top, $50 \mu \mathrm{m}$; bottom, $10 \mu \mathrm{m}$. C, Action potential firing patterns in MHb versus LHb neurons. Coronal

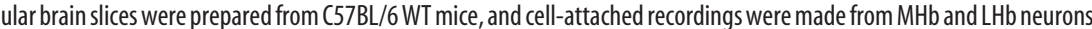
A representative trace is shown from a typical cell-attached recording from a MHb and LHb neuron. $D$, In whole-cell configuration, action potential firing in response to hyperpolarizing current $(-50 \mathrm{pA})$ injections was recorded in $\mathrm{MHb}$ and $\mathrm{LHb}$ neurons. Representative traces show the latency to recovery of action potential firing, as well as the action potential firing frequency, after cessation of current injection. $\boldsymbol{E}$, Responses to nicotine puffs in ChAT $(+)$ and ChAT $(-)$ MHb neurons. MHb neurons were voltageclamped at $-60 \mathrm{mV}$, and nicotine ( $30 \mu \mathrm{m}, 250 \mathrm{~ms}$ ) was puff-applied to the cell using a Picopump. Representative inward current deflections are shown for applications of nicotine at the indicated concentration. Responses from ChAT $(+)$ and ChAT $(-)$ neurons are shown. ChAT expression was later determined and assigned to each cell with a nicotine puff response as described in $\boldsymbol{F}$. F, ChAT expression in $\mathrm{MHb}$ cells. For cells studied in $\boldsymbol{E}$, neurobiotin was included in the patch pipette internal solution to mark the recorded cell. After successful nicotine puff experiments, neurobiotin-filled cells in slices were recovered and double-stained with streptavidin-Alexa-488 conjugates and anti-ChAT antibodies. A representative $\mathrm{ChAT}(+)$ and $\mathrm{ChAT}(-) \mathrm{MHb}$ neuron that was studied with nicotine puffs is shown. The wide micrograph shows the location of the cell in the MHb. Inset shows whether the cell was ChAT (+) (yellow color) or ChAT (-) (green color). Scale bars: $50 \mu \mathrm{m}$; inset, $10 \mu \mathrm{m}$.

the $\mathrm{MHbV}, \alpha 4$ was restricted to MHbVL, $\alpha 6$ was largely restricted to MHbVI plus the MHbDC, and $\beta 2$ and $\beta 3$ subunits were found in MHbVI and MHbVC (Fig. 5A). All subunits were found in some/many ChAT $(+) \mathrm{MHbV}$ neurons, but we also found evidence for $\alpha 3, \alpha 4$, and $\alpha 6$ subunits localized to $\operatorname{ChAT}(-)$ cells (Fig. 5A). In contrast, nearly all cells that were immunoreactive for $\beta 2, \beta 3$, and $\beta 4$ subunits were also $\operatorname{ChAT}(+)$ (Fig. $5 B$ ).

We were interested to further explore the possibility that ChAT $(-)$ cells contained functional nAChRs, so we studied $\mathrm{MHbV}$ neurons and $\mathrm{nAChR}$ function using patch-clamp electrophysiology in brain slices from C57BL/6 mice. First, we devel- 
A

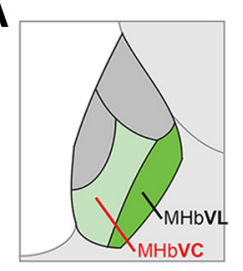

B

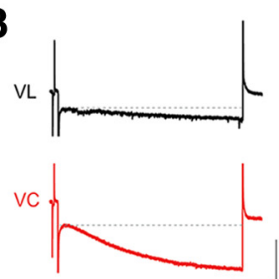

C

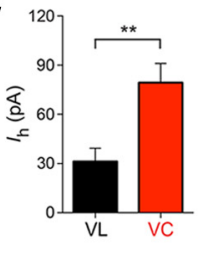

$E$

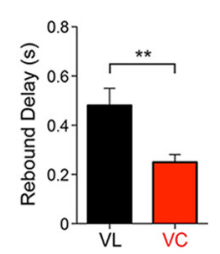

$\mathbf{F}$

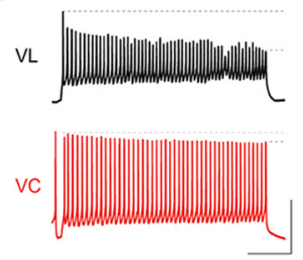

$\mathbf{J}$

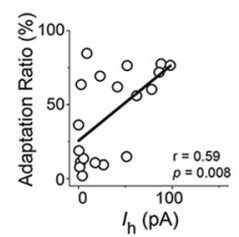

G

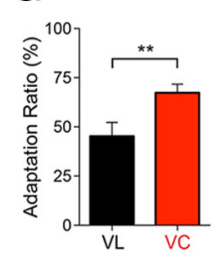

$\mathbf{K}$

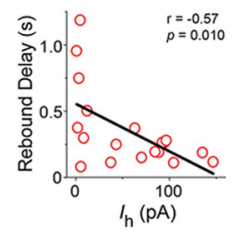

Figure 6. Electrophysiological properties of MHbVL and MHbVC neurons. $A$, Diagram of approximate location of MHbVL and MHbVC. $B$, Hyperpolarization-activated cation currents $\left(I_{h}\right)$ in MHbVC and MHbVL. MHb neurons were voltage-clamped at -60 $\mathrm{mV}$, and the command voltage was pulsed to $-120 \mathrm{mV}$ for $1 \mathrm{~s}$. The amplitude of the voltage-dependent inward current response was measured beginning with the current value at the end of the capacitive transient (indicated by the broken line), ending with the current value at the end of the voltage step. Representative $I_{h}$ current traces are shown for MHbVL and MHbVC cells. Calibration: $100 \mathrm{pA}, 200 \mathrm{~ms}$. C, Quantification of $\mathrm{I}_{\mathrm{h}}$ currents. A bar graph is shown for all recorded MHbVC $(n=13)$ and MHbVL $(n=18)$ cells. ${ }^{* *} p<0.01$ (unpaired $t$ test). D, Measurement of rebound (anode break) delay in MHbVC and MHbVL neurons. MHb neurons recorded in whole-cell configuration were current-clamped $(I=0)$, followed by injection of hyperpolarizing $(-75 \mathrm{pA})$ current. The latency to firing an action potential after the end of the pulse (from the broken line to the arrowhead) was measured for MHbVC and MHbVL neurons. Representative current traces are shown for MHbVL and MHbVC cells. Calibration: $50 \mathrm{mV}, 200 \mathrm{~ms}$. E, Quantification of rebound delay responses. A bar graph is shown for all responses from $\operatorname{MHbVL}(n=18)$ and $\operatorname{MHbVC}(n=13)$ neurons. ${ }^{* *} p<0.01$ (unpaired $t$ test). $\boldsymbol{F}$, Action potential amplitude adaptation in MHb neurons. MHb neurons were current-clamped (I = 0 ), and depolarizing current $(50 \mathrm{pA})$ was injected. The amplitude of the first and last spike in the train was measured (between the two broken lines), and the adaptation ratio (last spike amplitude/first spike amplitude) was calculated for each cell. Calibration: 50 $\mathrm{mV}, 200 \mathrm{~ms}$. G, Quantification of adaptation ratio measurements from $\boldsymbol{F}$. A bar graph is shown for all adaptation ratio responses from MHbVL $(n=18)$ and MHbVC $(n=13)$ cells. ${ }^{* *} p<0.01$ (unpaired $t$ test). $\boldsymbol{H}$, J, For each recorded MHbVL ( $\boldsymbol{H}$; black open circles) and MHbVC (J; red open circles) neuron, $I_{\mathrm{h}}$ current amplitude was plotted on the $x$-axis, and rebound delay was plotted on the $y$-axis. Linear regression analysis was performed on the plotted data points, and $r^{2}$ and $p$ values are shown. $\boldsymbol{I}, \boldsymbol{K}$, For each recorded MHbVL $(\boldsymbol{l} ;$; black open circles) and MHbVC ( $\boldsymbol{K}$; red open circles) neuron, $I_{\mathrm{h}}$ current amplitude was plotted on the $x$-axis, and adaptation ratio was plotted on the $y$-axis. Linear regression analysis was performed on the plotted data points, and $r$ and $p$ values are shown.

oped the ability to distinguish MHb neurons from neurons in the adjacent lateral $\mathrm{Hb}(\mathrm{LHb})$. Whereas $\mathrm{MHb}$ neurons exhibited regular, tonic firing when action potentials were recorded in cellattached recordings (Fig. $5 \mathrm{C}$ ), LHb neurons were heterogeneous, frequently exhibiting phasic bursts of spontaneous action potentials followed by periods of inactivity (Fig. $5 C$ ). Further, "anode break" excitation differed between $\mathrm{MHb}$ and $\mathrm{LHb}$ neurons: in whole-cell mode, $\mathrm{MHb}$ neurons exhibited single action potentials following a brief hyperpolarizing current injection (anode break action potentials; Fig. 5D). In contrast, LHb neurons exhibited multiple lowamplitude anode break action potentials (Fig. 5D). The latency to action potential firing during anode break was often, but not always, shorter in LHb cells versus MHb cells (Fig. 5D).

Having established criteria to distinguish $\mathrm{MHb}$ from $\mathrm{LHb}$ neurons, we next recorded inward currents in response to nicotine in $\operatorname{ChAT}(+)$ and $\operatorname{ChAT}(-)$ neurons. For both $\operatorname{ChAT}(+)$ and ChAT $(-)$ cells, we recorded robust responses to nicotine (30 $\mu \mathrm{M})$ (Fig. 5E). Cells displaying nicotine-elicited inward currents

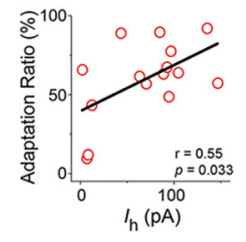

were verified as $\operatorname{ChAT}(+)$ or $\operatorname{ChAT}(-)$ by filling with neurobiotin, double-staining with streptavidin-Alexa-488 conjugate and anti-ChAT antibodies, and confocal imaging. Representative $\mathrm{ChAT}(+)$ and ChAT $(-)$ cells displaying nicotineelicited inward currents are shown (Fig. $5 F)$. These results suggest that $\mathrm{nAChR}$ function is not restricted to $\operatorname{ChAT}(+)$ cells in MHbV. Neurons studied in subsequent recordings reported below were not analyzed for ChAT expression status.

Based on differences in localization of $\mathrm{nAChR}$ subunits within regions of $\mathrm{MHbV}$ (Fig. 3), evidence for nAChRs in both ChAT $(+)$ and ChAT $(-)$ cells (Fig. 5), and emerging data showing specific gene expression in certain $\mathrm{MHb}$ to IPN circuits (Aizawa et al., 2012), we focused on distinguishing neurons within the MHbV region. In particular, we recorded from MHbVL and MHbVC neurons (Fig. 6A). In the cell-attached configuration, spontaneous action potential firing rates were similar in MHbVL and MHbVC neurons $(\mathrm{MHbVL}=4.3 \pm 0.5 \mathrm{~Hz}, \mathrm{MHbVC}=$ $5.0 \pm 0.6 \mathrm{~Hz}$; unpaired $t$ test, $p=0.208$ ). In whole-cell configuration, MHbVL and MHbVC neurons had a similar resting membrane potential when pipettes were filled with a $\mathrm{K}^{+}$-gluconate-based internal pipette solution $(\mathrm{MHbVL}=-42.2 \pm 1.7$ $\mathrm{mV}, \mathrm{MHbVC}=-42.6 \pm 1.7 \mathrm{mV}$; unpaired $t$ test, $p=0.429)$. In a measure of cellular excitability, we measured spike amplitude after a prolonged (1000 ms), depolarizing (50 pA) current injection (i.e., adaptation ratio) (Fig. 6F) (Bugaysen et al., 2010). MHbVL neurons exhibited significantly more decline in spike amplitude after depolarizing current injection compared with MHbVC neurons (Fig. 6G).

Tonic, spontaneous action potential firing (Fig. $5 \mathrm{C}$ ) suggested that $\mathrm{MHbV}$ neurons may express hyperpolarization-activated inward cation current ( $I_{\mathrm{h}}$ current). Both MHbVL and MHbVC neurons exhibited small but detectable $I_{\mathrm{h}}$ current in response to hyperpolarization (Fig. 6B), with MHbVC neurons exhibiting significantly more $I_{\mathrm{h}}$ current than MHbVL neurons (Fig. 6C). Differences in $I_{\mathrm{h}}$ current in MHbVL and MHbVC neurons suggested that these cells may respond differentially after hyperpolarizing current pulses. To test this idea, MHbVL and MHbVC neurons in current-clamp mode were briefly $(100 \mathrm{~ms})$ injected with hyperpolarizing $(-75 \mathrm{pA})$ current pulses, and the delay from the end of the pulse to the first action potential (i.e., rebound delay) was measured (Fig. 6D). MHbVL neurons exhibited a significantly longer rebound delay compared with MHbVC neurons (Fig. 6E), consistent with the idea that $I_{\mathrm{h}}$ currents activated during the hyperpolarizing pulse help to depolarize the neuron, allowing it to reach threshold more quickly.

Next, we used linear regression analysis and tested whether two of the electrophysiological parameters we recorded were cor- 
A
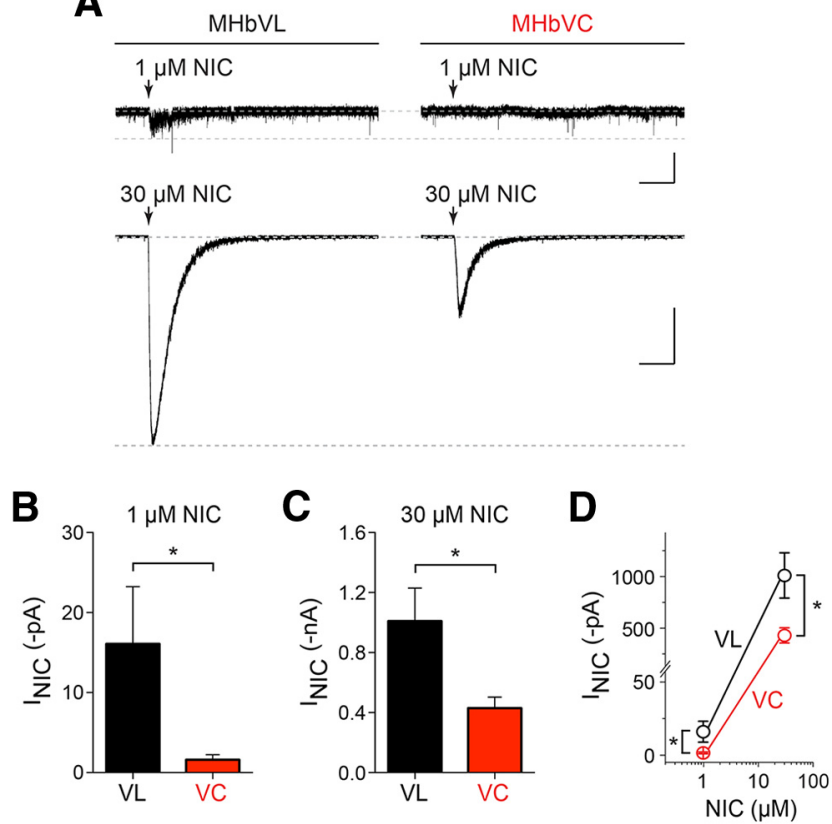

Figure 7. Nicotine-elicited inward currents in MHbV neurons. $\boldsymbol{A}, \mathrm{MHbVL}$ or MHbVC neurons were voltage-clamped at $-60 \mathrm{mV}$, and nicotine at the indicated concentration was puffapplied. Representative traces are shown for each nicotine concentration and cell type. Calibration: $1 \mu \mathrm{m}$ nicotine, $25 \mathrm{pA}, 5 \mathrm{~s} ; 30 \mu \mathrm{m}$ nicotine, $0.5 \mathrm{nA}, 5 \mathrm{~s}$. B. Mean nicotine (1 $\mu \mathrm{m}$ ) responses from MHbVL $(n=7)$ and MHbVC $(n=8)$ neurons are shown. ${ }^{*} p<0.05$ (unpaired $t$ test). $C$, Mean nicotine $(30 \mu \mathrm{M})$ responses from $\operatorname{MHbVL}(n=7)$ and $\operatorname{MHbVC}(n=7)$ neurons are shown. ${ }^{*} p<0.05$ (unpaired $t$ test). $\boldsymbol{D}$, Data from $\boldsymbol{B}$ and $\boldsymbol{C}$ are plotted together on a logarithmic scale. ${ }^{*} p<0.05$ (unpaired $t$ test).

related with expression of $I_{\mathrm{h}}$ current. In both MHbVL and MHbVC neurons, $I_{\mathrm{h}}$ current amplitude (at $V_{\mathrm{m}}=-120 \mathrm{mV}$ ) was anti-correlated with rebound delay (Fig. $6 \mathrm{H}, \mathrm{J}$ ). Similarly, in both MHbVL and MHbVC neurons, $I_{\mathrm{h}}$ current was positively correlated with adaptation ratio (Fig. 6I,K) (Bugaysen et al., 2010). These results, in addition to revealing differences between MHbVL and MHbVC neurons, indicate that $I_{\mathrm{h}}$ current may play a general role in shaping the excitability of MHbV neurons.

Based on differences in $\mathrm{nAChR}$ subunit localization between MHbVL and MHbVC neurons (Fig. 3), and in part due to our results showing differences in excitability between these two regions of MHbV (Fig. 6), we next studied nAChR function in MHbVL and MHbVC cells using puff-application of nicotine. MHbVL and MHbVC neurons were recorded in whole-cell configuration. Neurons were voltage-clamped at $-60 \mathrm{mV}$ and nicotine was puff-applied using a second drug-filled pipette positioned 20-40 $\mu \mathrm{m}$ from the recorded cell. Interestingly, $\mathrm{MH}-$ bVL neurons exhibited small but detectable responses to $1 \mu \mathrm{M}$ nicotine (Fig. $7 A, B$ ). MHbVC neurons, on the other hand, did not respond appreciably to this concentration of nicotine (Fig. $7 A, B, D)$. Both MHbVL and MHbVC neurons responded with inward currents following puff-application of $30 \mu \mathrm{M}$ nicotine, but mean responses in MHbVL neurons were, again, larger than in MHbVC neurons (Fig. 7C,D).

Although nicotine typically achieves concentrations of 50$200 \mathrm{~nm}$ in the CSF of smokers, concentrations of nicotine as high as $1 \mu \mathrm{M}$ have been reported as well (Malkawi et al., 2009). Because nAChRs in MHbVL neurons are sensitive to $1 \mu \mathrm{M}$ nicotine, we tested the idea that MHbVL neurons would respond to prolonged ( $\sim 10 \mathrm{~min}$ ) exposure to $1 \mu \mathrm{M}$ nicotine with altered action potential firing. Cell-attached recordings were made from
MHbVL and MHbVC neurons, followed by bath application of 1 $\mu \mathrm{M}$ nicotine. Whereas $\mathrm{MHbVC}$ neurons did not significantly change their firing in response to $1 \mu \mathrm{M}$ nicotine, MHbVL neurons exhibited a significant increase in firing rate relative to prenicotine baseline firing (Fig. $8 A, D, E$ ). Next, we sought to better understand the mechanism behind this difference in firing after nicotine application. Results from GFP-nAChR knock-in mice indicate that one defining factor of MHbVL neurons is their expression of $\alpha 4$ subunits (Fig. 3). Because $\alpha 4^{\star}$ nAChRs are among the most sensitive to nicotine and ACh (Salminen et al., 2004, 2007), we tested the idea that MHbVL sensitivity to $1 \mu \mathrm{M}$ nicotine (Fig. 8) required $\alpha 4$ subunits. We measured cell-attached firing in MHbVL neurons in slices from $\alpha 4$ knock-out mice, and we found that $1 \mu \mathrm{M}$ nicotine did not significantly increase firing above baseline levels (Fig. $8 B, D, E$ ). Next, because $\beta 4$ subunit levels are strong in MHbVL (Fig. $3 D$ ), we tested the hypothesis that $\beta 4$ subunits play a role in the response to $1 \mu \mathrm{M}$ nicotine in MHbVL cells. Pretreatment of cells with SR16584, a selective antagonist of $\alpha 3 \beta 4^{\star}$ nAChRs, eliminated the increase in action potential firing rate elicited by $1 \mu \mathrm{M}$ nicotine in MHbVL neurons (Fig. $8 C-E$ ). Together, these results point to a role for $\alpha 4$ and $\beta 4$ subunits, and likely nAChR pentamers containing both of these subunits, in the response of the MHb/IPN pathway to nicotine.

The MHb to IPN pathway is a key circuit mediating the somatic and affective signs of nicotine withdrawal in rodents, and presumably in humans. To determine whether MHbVL neurons play a role in nicotine withdrawal, we implanted C57BL/6 WT mice with osmotic minipumps delivering control saline or nicotine $(1 \mathrm{mg} / \mathrm{kg} / \mathrm{h})$ for $14 \mathrm{~d}$. To elicit withdrawal from nicotine, minipumps were removed, and brain slices were prepared for electrophysiology 18-24 h later (Fig. 9A). First, we measured nicotine-evoked currents using puff-application of 1 and $30 \mu \mathrm{M}$ nicotine. Compared with saline-withdrawn mice, there was a trend toward a decrease in nicotine-evoked currents in MHbVL neurons from nicotine-withdrawn mice at $1 \mu \mathrm{M}$ nicotine (Fig. $9 B, C)$. Furthermore, there was a significant reduction in nicotine-evoked current amplitudes in nicotine-withdrawn MHbVL neurons at $30 \mu \mathrm{M}$ nicotine (Fig. 9B,D). Next, we measured action potential firing in response to nicotine $(1 \mu \mathrm{M})$ reexposure in MHbVL neurons from nicotine- and saline-withdrawn mice. Consistent with a reduction in $\mathrm{nAChR}$ responsiveness seen in puff-application experiments (Fig. 9D), MHbVL neurons from nicotine-withdrawn mice exhibited a blunted response to nicotine application in cell-attached firing experiments (Fig. 9E). Although raw baseline and nicotine-evoked firing rates in nicotine- and saline-withdrawn mice were similar (Fig. 9F), nicotine-withdrawn MHbVL neurons did not respond to $1 \mu \mathrm{M}$ nicotine application with as large an increase in firing rate as salinewithdrawn MHbVL neurons (Fig. 9G). To verify that our minipump procedure did indeed deliver chronic nicotine to mice, we conducted a control experiment. Mice implanted with saline- or nicotine-containing minipumps for $14 \mathrm{~d}$ were given an intraperitoneal injection of mecamylamine $(1 \mathrm{mg} / \mathrm{kg})$ to precipitate withdrawal from chronic nicotine, and mice were perfused 90 min later for immunohistochemical analysis. Coronal sections containing the IPN were stained for c-Fos induction, and we noted a large increase in c-Fos-immunoreactive neurons in the IPN of mecamylamine-injected mice treated with chronic nicotine versus mecamylamine-injected mice treated with chronic saline (Fig. 9H). This result parallels a recent result obtained by Tapper and colleagues, who demonstrated that nicotine withdrawal results in activation of GABAergic neurons in the IPN (Zhao-Shea et al., 2013). 
A

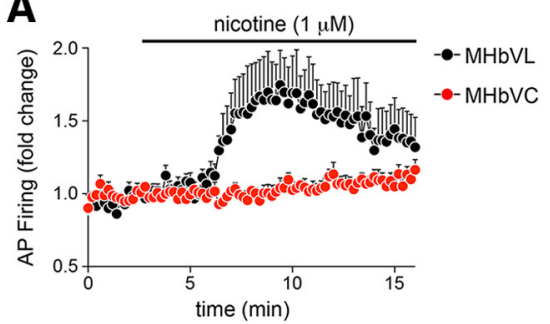

B

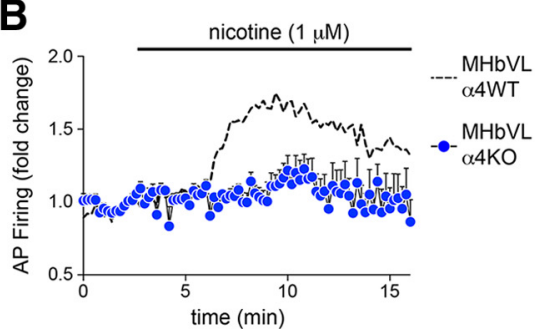

C

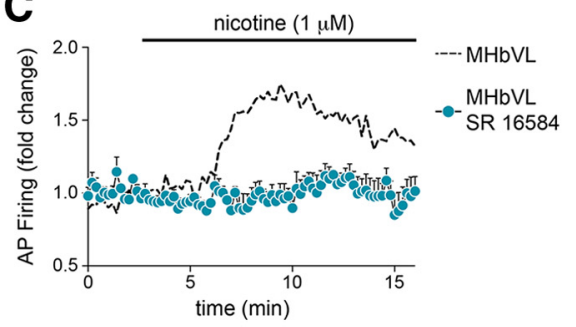

D

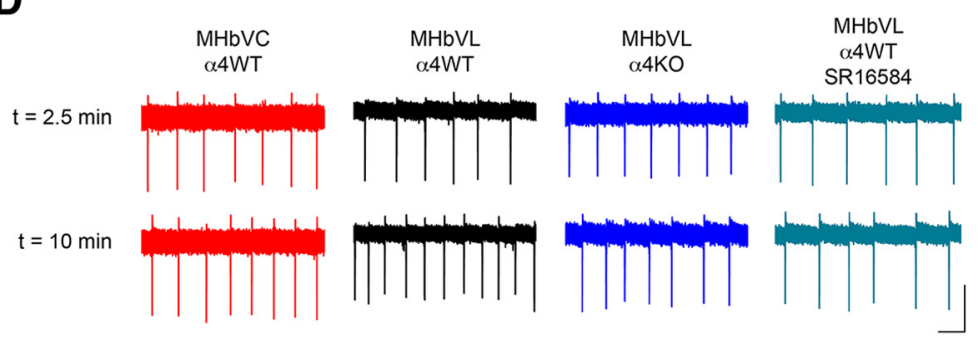

E

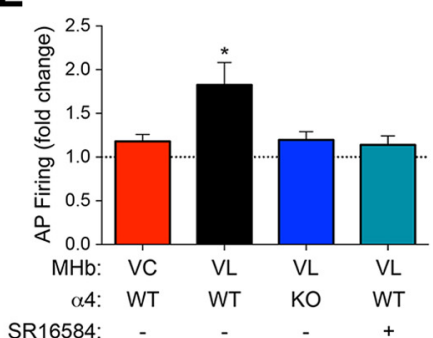

Figure 8. $\alpha 3 \beta 4^{*}$ and/or $\alpha 4^{*}$ nAChRs drive nicotine-elicited firing in MHbVL neurons. $\boldsymbol{A}$, Cell-attached recordings from MHbVL $(n=8)$ and MHbVC $(n=8)$ neurons were established, and baseline firing was recorded for several minutes, followed by superfusion of nicotine $(1 \mu \mathrm{M})$. Normalized firing rate is plotted, with baseline firing before nicotine application set to $1.0 . \mathbf{B}$, Cell-attached recordings from $\alpha 4 \mathrm{KOMHbVL}$ neurons $(n=9)$ were conducted. As in $A$, baseline firing was recorded followed by firing in response to superfusion of $1 \mu \mathrm{m}$ nicotine. Data from MHbVL WT neurons shown in $A$ are replotted for reference using dashed lines and no symbols. C, Cell-attached recordings from WT MHbVL neurons $(n=6)$ were conducted in response to SR16584, a putative $\alpha 3 \beta 4^{*}$ nAChR antagonist. Baseline firing was recorded for several minutes, followed by superfusion of SR16584 $(20 \mu \mathrm{M})$, then superfusion of nicotine (1 $\left.\mu \mathrm{M}\right)$ plus SR16584. Data from MHbVL WT neurons shown in $\boldsymbol{A}$ (response to $1 \mu \mathrm{m}$ nicotine alone) are replotted for reference using dashed lines and no symbols. $\boldsymbol{D}$, Representative traces from cell-attached firing experiments described in $A-C$. A sample current trace from $t=2.5 \mathrm{~min}$ (baseline) and $t=10 \mathrm{~min}$ (in $1 \mu \mathrm{m}$ nicotine) is shown for the indicated cell type, genotype, and/or pharmacological treatment. Calibration: $20 \mathrm{pA}, 200 \mathrm{~ms}$. $\boldsymbol{E}$, Quantification of data shown in $\boldsymbol{A}-\boldsymbol{C}$. For each cell from each of 4 conditions described in $\boldsymbol{A}-\boldsymbol{C}$, the fold change in action potential firing was derived compared with predrug firing. A bar graph is shown for these 4 conditions. ${ }^{*} p<0.05$ (paired $t$ test comparing predrug firing and peak firing during drug application for each cell).

To further study MHbVL to IPN circuitry, we recorded from IPN neurons in the IPR and IPDM. These areas, according to our immunohistochemistry data (Fig. 4), display high and specific expression of $\alpha 4 \mathrm{nAChR}$ subunits that largely originate in MHbVL. IPR/IPDM neurons were recorded in whole-cell configuration, first in current-clamp mode. Most IPR/IPDM neurons recorded from (19 of 25 ) did not fire spontaneously, and had an average resting membrane potential of $-62 \pm 1 \mathrm{mV}$. Interestingly, when positive current was injected during current-clamp recordings, two responses were evident. One class of cells was less sensitive to current injection, responding to positive current injection with moderate increases in firing (Fig. 10A, left). The other class of cells (Fig. 10A, right) was comparatively more sensitive to positive current injection and tended to exhibit rapid $(>100 \mathrm{~Hz}$ ) (Fig. 10D), phasic bursts of action potentials (Fig. $10 \mathrm{~A}$, right). For subsequent experiments (described below), we first recorded firing responses in current-clamp mode, and slower-firing and faster-firing neurons were classified as Type I and Type II IPR/IPDM neurons, respectively.

$\mathrm{MHb}$ neurons express cholinergic and glutamatergic markers, and in optogenetic experiments, appear to use both ACh and glutamate to signal to IPN neurons (Ren et al., 2011). Thus, we reasoned that some IPN neurons likely express and use AMPAtype glutamate receptors (AMPARs). To study AMPARs, we puff-applied AMPA to IPR/IPDM neurons held in voltage-clamp mode similar to our previous study (Engle et al., 2013). As with action potential firing, we found two types of responses to AMPA that cosegregated with action potential firing in response to positive current injection. Type I IPR/IPDM neurons exhibited responses to puffed AMPA $(100 \mu \mathrm{M})$ that were relatively small $(-273.4 \pm 30 \mathrm{pA}$; Fig. 10B, left), with a slower deactivation time constant of $16.7 \pm 3 \mathrm{~s}$. By contrast, Type II IPR/IPDM neurons were found to have com- paratively larger $(-1292.0 \pm 116 \mathrm{pA}$; Fig. 10B, right) responses to AMPA with a much more rapid deactivation time constant of $5.7 \pm$ $1 \mathrm{~s}$. To determine whether these differences in response to AMPA were due to greater potency of AMPA or greater efficacy of AMPA, we studied AMPA concentration-response relations for Type I and Type II IPR/IPDM neurons. The AMPA concentration-response data from Type I neurons were fitted $\left(r^{2}=0.60\right)$ to a monophasic function (Fig. 10E), with an $\mathrm{EC}_{50}$ of $30.5 \mu \mathrm{M}$. Interestingly, AMPA concentration-response data from Type II neurons fit well $\left(r^{2}=\right.$ 0.87 ) to a biphasic function. The higher-sensitivity component had an $\mathrm{EC}_{50}$ of $3.3 \mu \mathrm{M}$, whereas the lower-sensitivity component had an $\mathrm{EC}_{50}$ of $53.7 \mu \mathrm{M}$. These differences in AMPAR function in Type I and Type II IPR/IPDM neurons suggest that AMPAR expression may be greater in Type II IPR/IPDM neurons or that different AMPAR subtypes are expressed in these two populations.

Our immunohistochemistry data (Fig. 4) suggest a prominent role for MHb-derived, presynaptic nAChRs in IPN. Our data do not, however, rule out a postsynaptic role for some nAChR subtypes in IPN. Several studies suggest a postsynaptic role for nAChRs in IPN (Wada et al., 1989; Hsu et al., 2013). To study the action of nicotine on IPR/IPDM neurons and to further characterize Type I and Type II IPR/IPDM neurons, we studied responses to puffed nicotine. Like firing responses and AMPAevoked currents, nicotine-evoked currents exhibited a bimodal distribution: Type II neurons responded to $10 \mu \mathrm{M}$ nicotine with larger-amplitude currents compared with Type I neurons (Fig. $10 C, F)$. This difference was also evident in responses to $1 \mu \mathrm{M}$ nicotine (Fig. 10F). Together, these recordings in two types of IPR/IPDM neurons reveal interesting differences between these cell types in excitability and coupling to glutamatergic and cholinergic afferents from MHbVL. 


\section{Discussion}

\section{nAChR expression in MHb to} IPN pathway

In this study, we used newly developed nAChR-GFP knock-in mice to localize nAChR subunits in $\mathrm{MHb}$ neurons at subcellular resolution. Our data demonstrating localization of $\alpha 3$ and $\beta 4$ subunits throughout the MHbV area are consistent with previous reports using antibody staining or Western blotting (Yeh et al., 2001; Gahring et al., 2004), radioligand binding (Salas et al., 2004), mRNA in situ hybridization (Wada et al., 1989; WinzerSerhan and Leslie, 1997; Quik et al., 2000), and transgenic approaches (Frahm et al., 2011). Because most previous attempts to visualize $\mathrm{nAChR}$ subunits in $\mathrm{MHb}$ or IPN relied on radioligand binding, $\alpha 3 \beta 4^{*}$ nAChR binding failed to resolve cellular details of subunit location. Although $\alpha 4$ nAChR subunits were previously localized to MHbVL (Fonck et al., 2009), this is the first report demonstrating such a specific pattern for $\beta 2, \beta 3$, and $\alpha 6$ subunits.

We take particular note that $\alpha 4, \alpha 6$, $\beta 2$, and $\beta 3$ subunits exhibit a localization "gradient" across both the MHb and IPN. $\alpha 4$ subunits are confined to MHbVL and, in IPN, are localized preferentially in IPR and IPDM (Fig. 11C). Conversely, $\alpha 6$ subunits are confined to MHbVI and exhibit weak but detectable levels in the ventral IPR and in IPC (Fig. 11A). $\beta 2 \mathrm{MHbV}$ localization is somewhat similar to $\alpha 6$, being stronger in MHbVI and weaker in MHbVC and MHbVL (Fig. 11A-C). $\beta 2$ IPN localization is largely uniform from dorsal to ventral but is notably absent from IPR in caudal IPN sections. Last, $\beta 3$ subunit levels are strong in MHbVI and MHbVC (Fig. 11A,B), but comparatively weaker in MHbVL. In a similar manner, IPN $\beta 3$ levels are strong, except in IPDM and/or dorsal IPR. A gradient pattern for $\mathrm{MHb}$ molecular markers has been seen by other investigators. Aizawa et al. (2012) reported differential expression of markers in subdivisions of $\mathrm{MHb}$, including tachykinin 1 , vesicular glutamate transporter 1 and 2 , the $\mu$ opioid receptor, and the orphan GPCR Gpr151. Because IPN receives dense innervations from $\mathrm{MHb}$ via the FR, the patterns seen for $\alpha 4, \alpha 6, \beta 2$, and $\beta 3$ suggest that specific subdivisions of $\mathrm{MHb}$ project to specific areas in IPN. Our data support previous observations that MHbVL projects largely to IPR/IPDM, whereas MHbVI projects preferentially to IPC (Contestabile and Flumerfelt, 1981). If nAChR activation in MHbVI and/or MHbVL can control neuronal excitability in these areas, then ligands specific for $\alpha 4^{\star}$ or $\alpha 6^{*}$ $n A C h R s$ could specifically control the activity of cells in IPR/IPDM or IPC, respectively.

The extremely high density of $\mathrm{nAChRs}$ in $\mathrm{MHb}$ axons allowed us to visualize the FR. Interestingly, $\mathrm{MHb}$ axons exit the $\mathrm{MHb}$ at two distinct sites, then merge to form the FR. Micrographs of $\alpha 3$ and $\beta 4 \mathrm{MHb}$ localization clearly show axons exiting the $\mathrm{MHb}$ from the extreme ventral tip (either MHbVC or MHbVI) as well as in a more lateral direction from MHbVL (Fig. 3). We termed these exit sites the "ventral" and "lateral" exit sites. $\beta 2$ subunitcontaining axons entered the FR primarily via the ventral exit site, whereas $\alpha 4$-containing axons entered the FR from the lateral exit site. $\beta 3$-containing exons entered the FR through both exit sites, and $\alpha 6$ subunit levels were too weak to clearly visualize any axons. The lateral and ventral exit sites that are defined by nAChR subunit content may correspond to the central and subependymal branches, respectively, of the medial root of the FR (Andres et al., 1999).

The FR undergoes putative excitotoxic degeneration after exposure to high concentrations of nicotine (Carlson et al., 2000, 

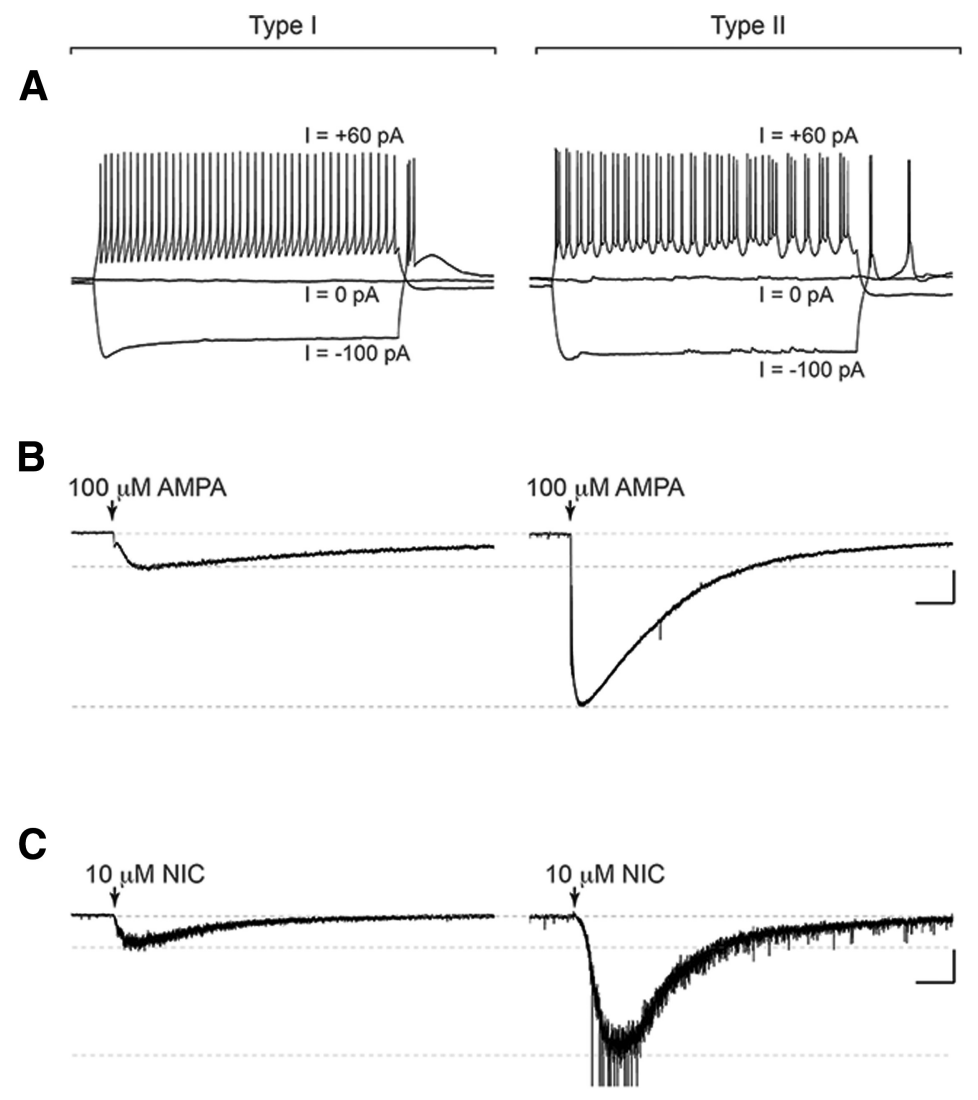
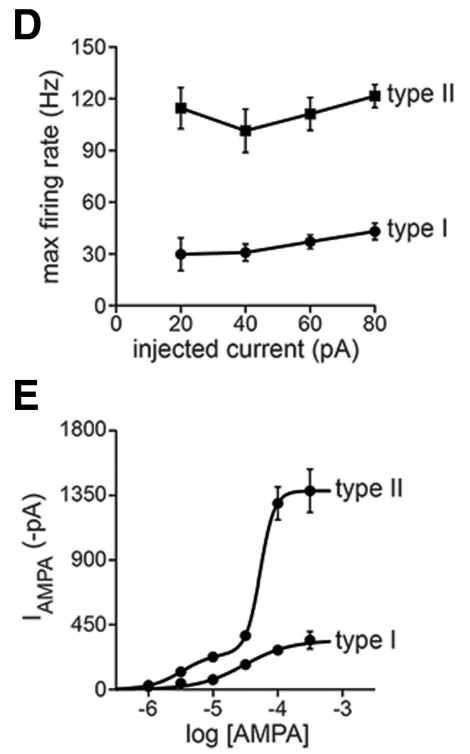

F

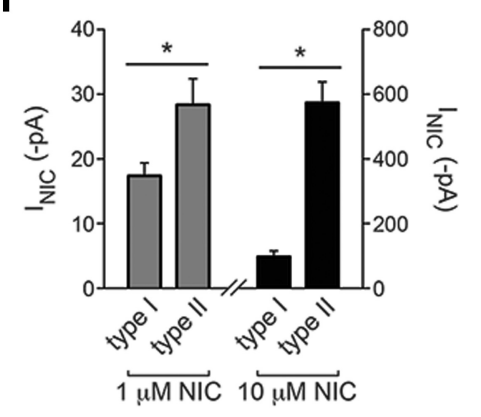

Figure 10. IPR/IPDM neuron populations receiving input from MHbVL. $\boldsymbol{A}$, IPR/IPDM neurons recorded in whole-cell configuration were held in current-clamp mode, and action potential firing was recording while the indicated amount of positive or negative current was injected. Based on the pattern of action potential firing, cells were classified as Type I or Type II. $\boldsymbol{B}$, Type I or Type II IPR/IPDM neurons were voltage-clamped at $-60 \mathrm{mV}$, and AMPA $(100 \mu \mathrm{M})$ was puff-applied. Representative traces are shown for each cell type. Calibration: 300 pA, 2 s. C, Type I or Type II IPR/IPDM neurons were voltage-clamped at $-60 \mathrm{mV}$, and nicotine (10 $\mu \mathrm{m})$ was puff-applied. Representative traces are shown for each cell type. Calibration: $100 \mathrm{pA}, 2 \mathrm{~s}$. D, Quantification of action potential firing from $A$. Action potential firing after injection of the indicated amount of positive current was recorded, and the maximum instantaneous firing rate was derived and plotted for each current injection. The number of neurons analyzed was as follows: $n=16$ (Type I), $n=9$ (Type II). E, AMPA concentration response relation for Type I and Type II IPR/IPDM neurons. AMPA-evoked inward

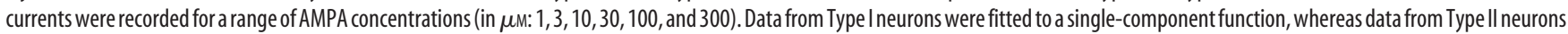
were fitted to a biphasic function. The number of Type I neurons analyzed for each AMPA concentration was as follows: $n=3(1 \mu \mathrm{m}), n=3(3 \mu \mathrm{m}), n=7(10 \mu \mathrm{m}), n=4$ ( $30 \mu \mathrm{m}), n=16(100$ $\mu \mathrm{M}), n=6(300 \mu \mathrm{m})$. The number of Type II neurons analyzed for each AMPA concentration was as follows: $n=2(1 \mu \mathrm{M}), n=2(3 \mu \mathrm{M}), n=4(10 \mu \mathrm{m}), n=3(30 \mu \mathrm{m}), n=9(100 \mu \mathrm{m}), n=3$ $(300 \mu \mathrm{M}) . \boldsymbol{F}$, Quantification of nicotine-evoked currents in Type I and Type II IPR/IPDM neurons. Cells were voltage-clamped at $-60 \mathrm{mV}$, nicotine (1 and $10 \mu \mathrm{m})$ was puff-applied, and mean values are plotted. The number of Type I neurons analyzed for each nicotine concentration was as follows: $n=7$ ( $1 \mu \mathrm{m}), n=7$ (10 $\mu \mathrm{m})$. The number of Type II neurons analyzed for each nicotine concentration was as follows: $n=7(1 \mu \mathrm{m}), n=7(10 \mu \mathrm{m}) .{ }^{*} p<0.05$ (unpaired $t$ test).

2001), possibly due to activation of nAChRs that do not strongly desensitize (Labarca et al., 2001). $\alpha 4 \beta 4^{\star}$ nAChRs appear to show reduced desensitization compared with $\beta 2^{\star}$ nAChRs (Lax et al., 2002), and in this study we have shown evidence for expression of this subtype in MHbVL neurons. nAChR-GFP mice will be useful in future experiments studying the relationship between $\mathrm{nAChR}$ activity and FR degeneration.

Surprisingly, nAChRs were not always seen within ChAT $(+)$ neurons. Anti-ChAT staining has been used as a marker for the MHbV (Fowler et al., 2011; Frahm et al., 2011; Ren et al., 2011), and optogenetics experiments use the ChAT promoter to direct expression of channelrhodopsin and to therefore "control" MHbV activity (Ren et al., 2011; Hu et al., 2012). Most neurons expressing $\alpha 3, \beta 3$, and $\beta 4$ subunits were ChAT-immunopositive, consistent with their role in regulating ACh release in IPN (Grady et al., 2009). However, $\alpha 6$ and $\alpha 4$ subunits were often found in neurons that were $\mathrm{ChAT}(-)$. Future experiments will be re- quired to determine what neurotransmitters these ChAT $(-)$ neurons release and how nAChRs modulate their activity. Because recordings reported in Figures 6, 7, 8, and 9 are from neurons whose ChAT expression status was not studied, data from these studies may represent a pool of both $\operatorname{ChAT}(+)$ and ChAT $(-)$ neurons.

\section{nAChR function in MHbV neurons}

Consistent with a previous (Kim and Chang, 2005) and a more recent (Görlich et al., 2013) report, we found that some $\mathrm{MHb}$ neurons exhibited spontaneous, tonic action potential firing in slice preparations. This tonic firing in $\mathrm{MHb}$ neurons is likely the result, at least in part, of expression of $\mathrm{HCN}$ channels and hyperpolarization-activated cation current $\left(I_{\mathrm{h}}\right)$ (Görlich et al., 2013). Although $I_{\mathrm{h}}$ current amplitudes in MHb neurons are smaller than those seen in SN pars compacta or VTA dopamine neurons (Engle et al., 2013), our analysis suggests an important 
role for $I_{\mathrm{h}}$ in shaping $\mathrm{MHb}$ neuron excitability. This is supported by a recent report, which demonstrated that inhibition of $\mathrm{MHb} \mathrm{HCN}$ channel activity can elicit behaviorally relevant changes in IPN activity (Görlich et al., 2013). $I_{\mathrm{h}}$ current amplitudes in individual cells were positively correlated with that cell's ability to fire sustained and high-frequency trains of action potentials, and $I_{\mathrm{h}}$ current amplitude was negatively correlated with the latency to anode break firing (Fig. 6). These data suggest that $\mathrm{MHb}$ provides a tonic glutamatergic and/or cholinergic signal to IPN neurons (Grady et al., 2009; Ren et al., 2011; Hu et al., 2012).

Surprisingly, neurons in MHbVL, but not $\mathrm{MHbVC}$, were capable of responding to $1 \mu \mathrm{M}$ nicotine with responses similar in magnitude to those seen in rewardpathway VTA DA neurons at the same concentration of nicotine (Tapper et al., 2004; Drenan et al., 2008b). Furthermore, $1 \mu \mathrm{M}$ nicotine also augmented MHbVL neuron action potential firing in a manner similar to that seen in VTA DA neurons (Liu et al., 2012), and loss of $\alpha 4$ subunits eliminated this effect (Fig. 8). MHbVC neurons, which are devoid of $\alpha 4$ subunits, did not express nAChRs that were sensitive enough to $1 \mu \mathrm{M}$ nicotine to elicit inward currents (Fig. 7) or action potential firing (Fig. 8). Although SR16584 is generally considered a selective antagonist for $\alpha 3 \beta 4^{\star}$ nAChRs (Zaveri et al., 2010), it has not been tested on $\alpha 4 \beta 4^{\star}$ nAChRs, whose subunits are found in MHbVL and respond well to $1 \mu \mathrm{M}$ nicotine (Luetje and Patrick, 1991; Puskar et al., 2011). Our data also suggest that $\alpha 3 \beta 4^{\star} \mathrm{nAChRs}$ play a role in the ability of MHbVL to respond to $1 \mu \mathrm{M}$ nicotine (Fig. 8). Together, these recordings of action potential firing suggest at least two possibilities: (1) separable populations of $\alpha 3 \beta 4^{\star}$ and $\alpha 4^{\star}$ nAChRs may mediate nicotine's action in accelerating MHbVL neuron firing; or (2) $\alpha 3 \alpha 4 \beta 4^{*}$ receptors are at least partially responsible for the increase.

In contrast to $\alpha 4 \beta 2^{\star}$ nAChRs, $\alpha 4 \beta 4^{*}$ nAChRs are not expected to undergo marked upregulation in response to chronic nicotine (Srinivasan et al., 2011). In knock-in mice expressing YFP-labeled $\alpha 4$ subunits, $\alpha 4$ levels in MHb did not change significantly in response to chronic nicotine (Nashmi et al., 2007). Thus, if $\alpha 4 \beta 4^{\star}$ and/or $\alpha 3 \alpha 4 \beta 4^{\star} \mathrm{nAChRs}$ are expressed at high levels in MHbVL neurons, it would account for the blunted response to nicotine in these cells from nicotinewithdrawn mice (Fig. 9). A recent report corroborated our findings indicating that chronic nicotine reduces $\mathrm{MHb}$ neuronal excitability, although without determining which subregions of MHbV are involved (Dao et al., 2014). Together, these data suggest that reexposure of MHbVL neurons to nicotine after nico-
B

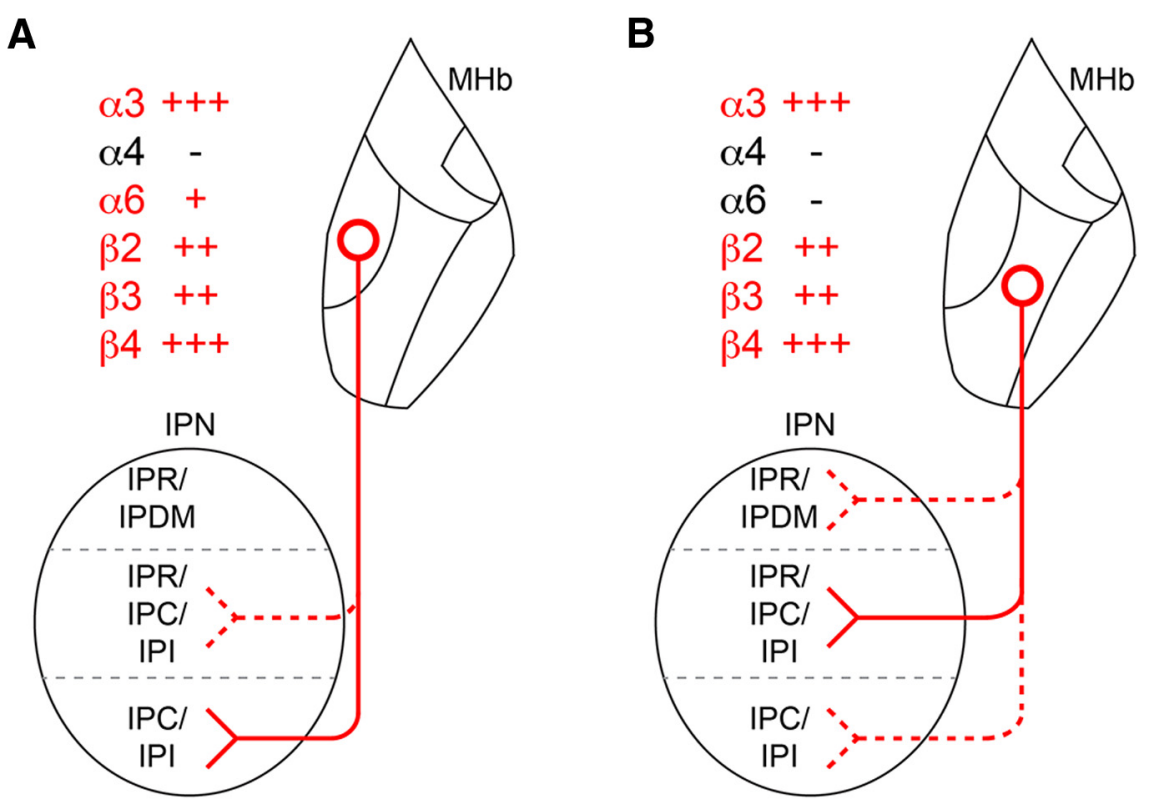

Figure 11. $n A C h R s$ and the MHbV to IPN pathway: summary schematic. $\boldsymbol{A}, \mathrm{nAChR}$-expressing cells of the MHbVI project preferentially to ventral IPN, and the indicated (red text) nAChR subunits are expressed in MHb somata and in presynaptic terminals in IPN. $\boldsymbol{B}$, MHbVC projects preferentially to central regions of IPN. C, MHbVL projects preferentially to IPR/IPDM. At least two cell types exist in IPR/IPDM. Type I neurons exhibit relatively small inward currents in response to puffed nicotine (NIC) and AMPA and fire tonic action potentials in response to positive current injection. Type II neurons exhibit relatively (compared with Type I cells) large inward currents in response to puffed NIC or AMPA and fire bursts of action potentials following positive current injection.

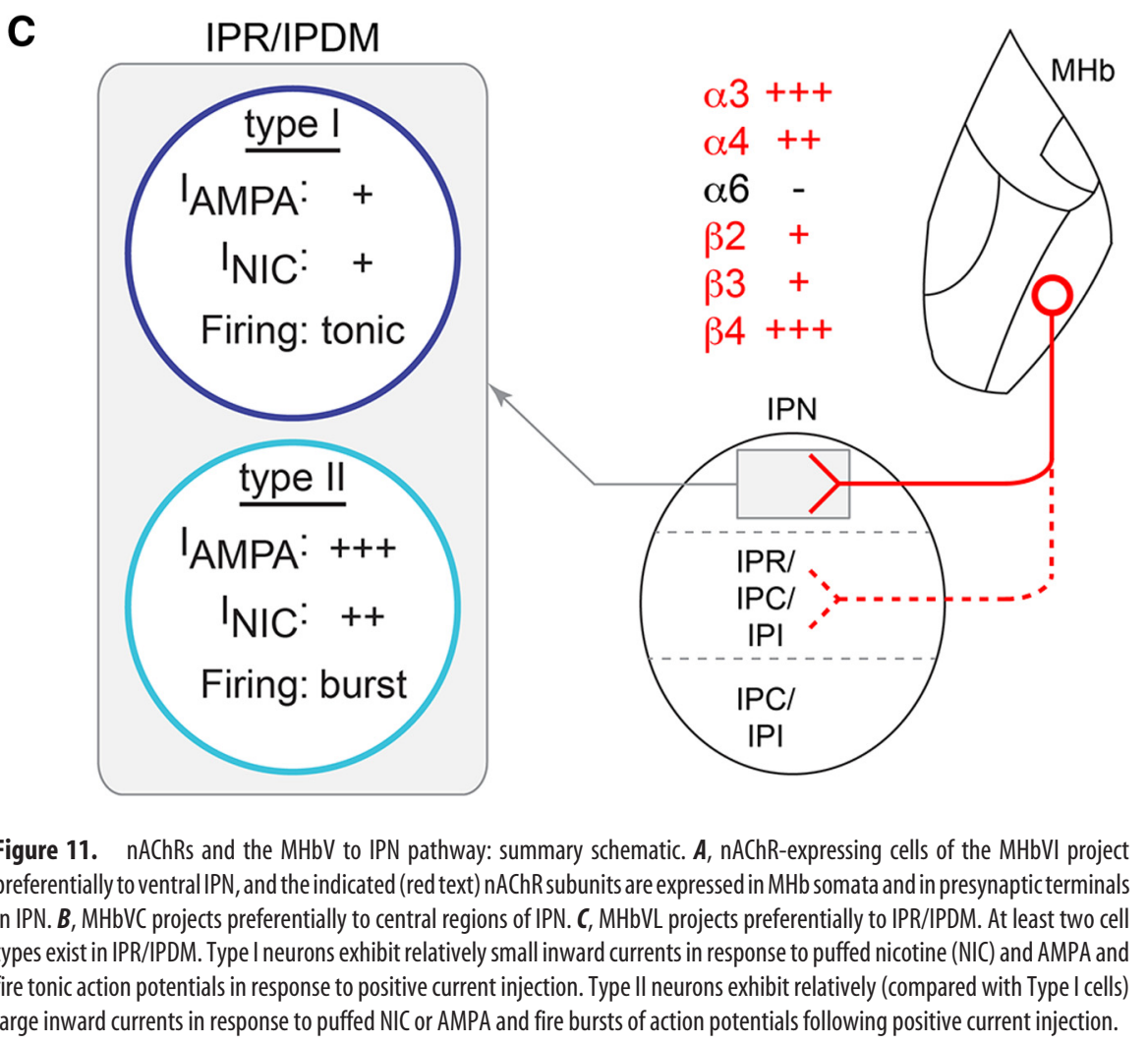

tine withdrawal may result in reduced firing of these neurons and reduced glutamate and/or ACh release onto IPR/IPDM target neurons. If IPR/IPDM cells receiving innervation from MHbVL neurons are GABAergic, as suggested recently (Hsu et al., 2013; Zhao-Shea et al., 2013), then reexposure to nicotine in nicotinewithdrawn animals could result in less activation of GABAergic IPR/IPDM neurons compared with nicotine exposure in control animals, which could ultimately contribute to relapse because of a reduction in aversive signals generated by the IPN (Fowler et al., 2011). Our withdrawal data highlight the importance of studying subregions of the MHb to IPN pathway, such as the MHbVL, as a 
recent study that did not restrict its analysis to specific MHbV areas found increased nicotine-evoked firing in neurons from nicotine-withdrawn mice (Görlich et al., 2013). Further, we recently found increased $\alpha 6$ subunit levels in MHbVI of mice treated chronically with nicotine (Henderson et al., 2014).

Our data reporting electrophysiologically distinct neuronal populations in IPR/IPDM (Fig. 10C) are novel and build upon recently published data suggesting the existence of distinct cellular populations in IPN (Hsu et al., 2013; Zhao-Shea et al., 2013). Compared with Type I IPR/IPDM neurons, Type II neurons may couple more strongly to cholinergic/glutamatergic input from MHbVL because of greater function of AMPA receptors (Fig. $10 B, E$ ) and a stronger response to nicotine (Fig. 10C,F). Overall, these studies provide new anatomical and mechanistic details regarding $\mathrm{nAChR}$ expression and function in the brain's key aversion pathway.

\section{References}

Aizawa H, Kobayashi M, Tanaka S, Fukai T, Okamoto H (2012) Molecular characterization of the subnuclei in rat habenula. J Comp Neurol 520: 4051-4066. CrossRef Medline

Andres KH, von Düring M, Veh RW (1999) Subnuclear organization of the rat habenular complexes. J Comp Neurol 407:130-150. CrossRef Medline

Bierut LJ, Madden PA, Breslau N, Johnson EO, Hatsukami D, Pomerleau OF, Swan GE, Rutter J, Bertelsen S, Fox L, Fugman D, Goate AM, Hinrichs AL, Konvicka K, Martin NG, Montgomery GW, Saccone NL, Saccone SF, Wang JC, Chase GA, et al. (2007) Novel genes identified in a highdensity genome wide association study for nicotine dependence. Hum Mol Genet 16:24-35. CrossRef Medline

Bierut LJ, Stitzel JA, Wang JC, Hinrichs AL, Grucza RA, Xuei X, Saccone NL, Saccone SF, Bertelsen S, Fox L, Horton WJ, Breslau N, Budde J, Cloninger CR, Dick DM, Foroud T, Hatsukami D, Hesselbrock V, Johnson EO, Kramer J, et al. (2008) Variants in nicotinic receptors and risk for nicotine dependence. Am J Psychiatry 165:1163-1171. CrossRef Medline

Bugaysen J, Bronfeld M, Tischler H, Bar-Gad I, Korngreen A (2010) Electrophysiological characteristics of globus pallidus neurons. PLoS One 5:e12001. CrossRef Medline

Carlson J, Armstrong B, Switzer RC 3rd, Ellison G (2000) Selective neurotoxic effects of nicotine on axons in fasciculus retroflexus further support evidence that this is a weak link in brain across multiple drugs of abuse. Neuropharmacology 39:2792-2798. CrossRef Medline

Carlson J, Noguchi K, Ellison G (2001) Nicotine produces selective degeneration in the medial habenula and fasciculus retroflexus. Brain Res 906: 127-134. CrossRef Medline

Contestabile A, Flumerfelt BA (1981) Afferent connections of the interpeduncular nucleus and the topographic organization of the habenulointerpeduncular pathway: an HRP study in the rat. J Comp Neurol 196: 253-270. CrossRef Medline

Contestabile A, Villani L, Fasolo A, Franzoni MF, Gribaudo L, Oktedalen O, Fonnum F (1987) Topography of cholinergic and substance $P$ pathways in the habenulo-interpeduncular system of the rat: an immunocytochemical and microchemical approach. Neuroscience 21:253-270. CrossRef Medline

Dao DQ, Perez EE, Teng Y, Dani JA, De Biasi M (2014) Nicotine enhances excitability of medial habenular neurons via facilitation of neurokinin signaling. J Neurosci 34:4273-4284. CrossRef Medline

Dineley-Miller K, Patrick J (1992) Gene transcripts for the nicotinic acetylcholine receptor subunit, $\beta 4$, are distributed in multiple areas of the rat central nervous system. Brain Res Mol Brain Res 16:339-344. CrossRef Medline

Drenan RM, Nashmi R, Imoukhuede P, Just H, McKinney S, Lester HA (2008a) Subcellular trafficking, pentameric assembly, and subunit stoichiometry of neuronal nicotinic acetylcholine receptors containing fluorescently labeled $\alpha 6$ and $\beta 3$ subunits. Mol Pharmacol 73:27-41. CrossRef Medline

Drenan RM, Grady SR, Whiteaker P, McClure-Begley T, McKinney S, Miwa JM, Bupp S, Heintz N, McIntosh JM, Bencherif M, Marks MJ, Lester HA (2008b) In vivo activation of midbrain dopamine neurons via sensitized, high-affinity $\alpha 6^{\star}$ nicotinic acetylcholine receptors. Neuron 60:123-136. CrossRef Medline
Engle SE, Broderick HJ, Drenan RM (2012) Local application of drugs to study nicotinic acetylcholine receptor function in mouse brain slices. J Vis Exp 68:e50034. CrossRef Medline

Engle SE, Shih PY, McIntosh JM, Drenan RM (2013) $\alpha 4 \alpha 6 \beta 2^{\star}$ nAChR activation on VTA DA neurons is sufficient to stimulate a depolarizing conductance and enhance surface AMPA receptor function. Mol Pharmacol 84:393-406. CrossRef Medline

Fonck C, Nashmi R, Salas R, Zhou C, Huang Q, De Biasi M, Lester RA, Lester HA (2009) Demonstration of functional $\alpha 4$-containing nicotinic receptors in the medial habenula. Neuropharmacology 56:247-253. CrossRef Medline

Fowler CD, Lu Q, Johnson PM, Marks MJ, Kenny PJ (2011) Habenular $\alpha 5$ nicotinic receptor subunit signalling controls nicotine intake. Nature 471: 597-601. CrossRef Medline

Frahm S, Slimak MA, Ferrarese L, Santos-Torres J, Antolin-Fontes B, Auer S, Filkin S, Pons S, Fontaine JF, Tsetlin V, Maskos U, Ibañez-TallonI (2011) Aversion to nicotine is regulated by the balanced activity of $\beta 4$ and $\alpha 5$ nicotinic receptor subunits in the medial habenula. Neuron 70:522-535. CrossRef Medline

Franklin KBJ, Paxinos G (2008) The Mouse Brain in Stereotaxic Coordinates, Ed 3. New York: Elsevier.

Gahring LC, Persiyanov K, Rogers SW (2004) Neuronal and astrocyte expression of nicotinic receptor subunit $\beta 4$ in the adult mouse brain. J Comp Neurol 468:322-333. CrossRef Medline

Görlich A, Antolin-Fontes B, Ables JL, Frahm S, Slimak MA, Dougherty JD, Ibañez-Tallon I (2013) Reexposure to nicotine during withdrawal increases the pacemaking activity of cholinergic habenular neurons. Proc Natl Acad Sci U S A 110:17077-17082. CrossRef Medline

Grady SR, Moretti M, Zoli M, Marks MJ, Zanardi A, Pucci L, Clementi F, Gotti C (2009) Rodent habenulo-interpeduncular pathway expresses a large variety of uncommon nAChR subtypes, but only the $\alpha 3 \beta 4^{*}$ and $\alpha 3 \beta 3 \beta 4^{*}$ subtypes mediate acetylcholine release. J Neurosci 29:22722282. CrossRef Medline

Henderson BJ, Srinivasan R, Nichols WA, Dilworth CN, Gutierrez DF, Mackey ED, McKinney S, Drenan RM, Richards CI, Lester HA (2014) Nicotine exploits a COPI-mediated process for chaperone-mediated upregulation of its receptors. J Gen Physiol 143:51-66. CrossRef Medline

Hsu YW, Tempest L, Quina LA, Wei AD, Zeng H, Turner EE (2013) Medial habenula output circuit mediated by $\alpha 5$ nicotinic receptor-expressing GABAergic neurons in the interpeduncular nucleus. J Neurosci 33: 18022-18035. CrossRef Medline

Hu F, Ren J, Zhang JE, Zhong W, Luo M (2012) Natriuretic peptides block synaptic transmission by activating phosphodiesterase $2 \mathrm{~A}$ and reducing presynaptic PKA activity. Proc Natl Acad Sci U S A 109:17681-17686. CrossRef Medline

Kim U, Chang SY (2005) Dendritic morphology, local circuitry, and intrinsic electrophysiology of neurons in the rat medial and lateral habenular nuclei of the epithalamus. J Comp Neurol 483:236-250. CrossRef Medline

Labarca C, Schwarz J, Deshpande P, Schwarz S, Nowak MW, Fonck C, Nashmi R, Kofuji P, Dang H, Shi W, Fidan M, Khakh BS, Chen Z, Bowers BJ, Boulter J, Wehner JM, Lester HA (2001) Point mutant mice with hypersensitive $\alpha 4$ nicotinic receptors show dopaminergic deficits and increased anxiety. Proc Natl Acad Sci U S A 98:2786-2791. CrossRef Medline

Lax P, Fucile S, Eusebi F (2002) Ca(2+) permeability of human heteromeric nAChRs expressed by transfection in human cells. Cell Calcium 32:53-58. CrossRef Medline

Liu L, Zhao-Shea R, McIntosh JM, Gardner PD, Tapper AR (2012) Nicotine persistently activates ventral tegmental area dopaminergic neurons via nicotinic acetylcholine receptors containing $\alpha 4$ and $\alpha 6$ subunits. Mol Pharmacol 81:541-548. CrossRef Medline

Luetje CW, Patrick J (1991) Both $\alpha$ - and $\beta$-subunits contribute to the agonist sensitivity of neuronal nicotinic acetylcholine receptors. J Neurosci 11:837-845. Medline

Mackey ED, Engle SE, Kim MR, O’Neill HC, Wageman CR, Patzlaff NE, Wang Y, Grady SR, McIntosh JM, Marks MJ, Lester HA, Drenan RM (2012) $\alpha 6^{\star}$ nicotinic acetylcholine receptor expression and function in a visual salience circuit. J Neurosci 32:10226-10237. CrossRef Medline

Malkawi AH, Al-Ghananeem AM, de Leon J, Crooks PA (2009) Nicotine exposure can be detected in cerebrospinal fluid of active and passive smokers. J Pharm Biomed Anal 49:129-132. CrossRef Medline 
Marks MJ, Pauly JR, Gross SD, Deneris ES, Hermans-Borgmeyer I, Heinemann SF, Collins AC (1992) Nicotine binding and nicotinic receptor subunit RNA after chronic nicotine treatment. J Neurosci 12:2765-2784. Medline

Nashmi R, Dickinson ME, McKinney S, Jareb M, Labarca C, Fraser SE, Lester HA (2003) Assembly of $\alpha 4 \beta 2$ nicotinic acetylcholine receptors assessed with functional fluorescently labeled subunits: effects of localization, trafficking, and nicotine-induced upregulation in clonal mammalian cells and in cultured midbrain neurons. J Neurosci 23:11554-11567. Medline

Nashmi R, Xiao C, Deshpande P, McKinney S, Grady SR, Whiteaker P, Huang Q, McClure-Begley T, Lindstrom JM, Labarca C, Collins AC, Marks MJ, Lester HA (2007) Chronic nicotine cell specifically upregulates functional $\alpha 4^{*}$ nicotinic receptors: basis for both tolerance in midbrain and enhanced long-term potentiation in perforant path. J Neurosci 27:82028218. CrossRef Medline

Perry DC, Xiao Y, Nguyen HN, Musachio JL, Dávila-García MI, Kellar KJ (2002) Measuring nicotinic receptors with characteristics of $\alpha 4 \beta 2, \alpha 3 \beta 2$ and $\alpha 3 \beta 4$ subtypes in rat tissues by autoradiography. J Neurochem 82 : 468-481. CrossRef Medline

Puskar NL, Xiu X, Lester HA, Dougherty DA (2011) Two neuronal nicotinic acetylcholine receptors, $\alpha 4 \beta 4$ and $\alpha 7$, show differential agonist binding modes. J Biol Chem 286:14618-14627. CrossRef Medline

Quick MW, Ceballos RM, Kasten M, McIntosh JM, Lester RA (1999) $\alpha 3 \beta 4$ subunit-containing nicotinic receptors dominate function in rat medial habenula neurons. Neuropharmacology 38:769-783. CrossRef Medline

Quik M, Polonskaya Y, Gillespie A, Jakowec M, Lloyd GK, Langston JW (2000) Localization of nicotinic receptor subunit mRNAs in monkey brain by in situ hybridization. J Comp Neurol 425:58-69. CrossRef Medline

Ren J, Qin C, Hu F, Tan J, Qiu L, Zhao S, Feng G, Luo M (2011) Habenula "cholinergic" neurons co-release glutamate and acetylcholine and activate postsynaptic neurons via distinct transmission modes. Neuron 69: 445-452. CrossRef Medline

Saccone NL, Saccone SF, Hinrichs AL, Stitzel JA, Duan W, Pergadia ML, Agrawal A, Breslau N, Grucza RA, Hatsukami D, Johnson EO, Madden PA, Swan GE, Wang JC, Goate AM, Rice JP, Bierut LJ (2009) Multiple distinct risk loci for nicotine dependence identified by dense coverage of the complete family of nicotinic receptor subunit (CHRN) genes. Am J Med Genet B Neuropsychiatr Genet 150B:453-466. CrossRef Medline

Saccone SF, Hinrichs AL, Saccone NL, Chase GA, Konvicka K, Madden PA, Breslau N, Johnson EO, Hatsukami D, Pomerleau O, Swan GE, Goate AM, Rutter J, Bertelsen S, Fox L, Fugman D, Martin NG, Montgomery GW, Wang JC, Ballinger DG, et al. (2007) Cholinergic nicotinic receptor genes implicated in a nicotine dependence association study targeting 348 candidate genes with 3713 SNPs. Hum Mol Genet 16:36-49. CrossRef Medline

Salas R, Pieri F, De Biasi M (2004) Decreased signs of nicotine withdrawal in mice null for the $\beta 4$ nicotinic acetylcholine receptor subunit. J Neurosci 24:10035-10039. CrossRef Medline

Salminen O, Murphy KL, McIntosh JM, Drago J, Marks MJ, Collins AC, Grady SR (2004) Subunit composition and pharmacology of two classes of striatal presynaptic nicotinic acetylcholine receptors mediating dopamine release in mice. Mol Pharmacol 65:1526-1535. CrossRef Medline

Salminen O, Drapeau JA, McIntosh JM, Collins AC, Marks MJ, Grady SR (2007) Pharmacology of $\alpha$-conotoxin MII-sensitive subtypes of nicotinic acetylcholine receptors isolated by breeding of null mutant mice. Mol Pharmacol 71:1563-1571. CrossRef Medline

Srinivasan R, Pantoja R, Moss FJ, Mackey ED, Son CD, Miwa J, Lester HA (2011) Nicotine up-regulates $\alpha 4 \beta 2$ nicotinic receptors and ER exit sites via stoichiometry-dependent chaperoning. J Gen Physiol 137:59-79. CrossRef Medline

Tapper AR, McKinney SL, Nashmi R, Schwarz J, Deshpande P, Labarca C, Whiteaker P, Marks MJ, Collins AC, Lester HA (2004) Nicotine activation of $\alpha 4^{*}$ receptors: sufficient for reward, tolerance, and sensitization. Science 306:1029-1032. CrossRef Medline

Wada E, Wada K, Boulter J, Deneris E, Heinemann S, Patrick J, Swanson LW (1989) Distribution of $\alpha 2, \alpha 3, \alpha 4$, and $\beta 2$ neuronal nicotinic receptor subunit mRNAs in the central nervous system: a hybridization histochemical study in the rat. J Comp Neurol 284:314-335. CrossRef Medline

Winzer-Serhan UH, Leslie FM (1997) Codistribution of nicotinic acetylcholine receptor subunit $\alpha 3$ and $\beta 4$ mRNAs during rat brain development. J Comp Neurol 386:540-554. CrossRef Medline

Xiao C, Nashmi R, McKinney S, Cai H, McIntosh JM, Lester HA (2009) Chronic nicotine selectively enhances $\alpha 4 \beta 2^{*}$ nicotinic acetylcholine receptors in the nigrostriatal dopamine pathway. J Neurosci 29:1242812439. CrossRef Medline

Xiao C, Srinivasan R, Drenan RM, Mackey ED, McIntosh JM, Lester HA (2011) Characterizing functional $\alpha 6 \beta 2$ nicotinic acetylcholine receptors in vitro: mutant $\beta 2$ subunits improve membrane expression, and fluorescent proteins reveal responsive cells. Biochem Pharmacol 82:852-861. CrossRef Medline

Yeh JJ, Yasuda RP, Dávila-García MI, Xiao Y, Ebert S, Gupta T, Kellar KJ, Wolfe BB (2001) Neuronal nicotinic acetylcholine receptor $\alpha 3$ subunit protein in rat brain and sympathetic ganglion measured using a subunitspecific antibody: regional and ontogenic expression. J Neurochem 77: 336-346. CrossRef Medline

Zaveri N, Jiang F, Olsen C, Polgar W, Toll L (2010) Novel $\alpha 3 \beta 4$ nicotinic acetylcholine receptor-selective ligands: discovery, structure-activity studies, and pharmacological evaluation. J Med Chem 53:8187-8191. CrossRef Medline

Zhao-Shea R, Liu L, Pang X, Gardner PD, Tapper AR (2013) Activation of GABAergic neurons in the interpeduncular nucleus triggers physical nicotine withdrawal symptoms. Curr Biol 23:2327-2335. CrossRef Medline 